AperTO - Archivio Istituzionale Open Access dell'Università di Torino

\title{
Omics analysis of oxysterols to better understand their pathophysiological role
}

\section{This is the author's manuscript}

Original Citation:

Availability:

This version is available http://hdl.handle.net/2318/1715534

since 2019-11-14T13:14:30Z

Published version:

DOI:10.1016/j.freeradbiomed.2019.05.026

Terms of use:

Open Access

Anyone can freely access the full text of works made available as "Open Access". Works made available under a Creative Commons license can be used according to the terms and conditions of said license. Use of all other works requires consent of the right holder (author or publisher) if not exempted from copyright protection by the applicable law. 


\title{
Manuscript Details
}

\section{Manuscript number}

Title

Article type
FRBM_2019_314

Omics analysis of oxysterols to better understand their pathophysiological role

Review Article

\begin{abstract}
High amounts of cholesterol have been definitely associated with the pathogenesis of several diseases, including metabolic and neurodegenerative disorders, cardiovascular diseases, and cancer. In all these pathologies the exacerbation of pro-oxidant and inflammatory responses is a consistent feature. In this scenario, species derived from enzymatic and non-enzymatic cholesterol oxidation, namely oxysterols, are strongly suspected to play a primary role. The consideration of these bioactive lipids is therefore helpful in investigating pathological mechanisms and may also acquire clinical value for the diagnosis and treatment of the disease. For this purpose and considering that a great number of oxysterols may be present together in the body, the employment of lipidomics technology certainly represents a powerful strategy for the simultaneous detection and characterization of these compounds in biological specimens. In this review we will discuss the applicability of lipidomics approach in the study of the association between oxysterols and diseases.
\end{abstract}

Keywords

Taxonomy

Manuscript category

Corresponding Author

Corresponding Author's Institution

Order of Authors

Suggested reviewers oxysterols; cholesterol; lipidomics; liquid- and gas-chromatography/massspectrometry; cardiovascular diseases; neurological diseases; metabolic disease; cancer; inflammation; oxidative stress.

Cholesterol, Lipid Oxidation, Inflammation, Liquid Chromatography Mass Spectrometry, Gas Chromatography Mass Spectrometry, Biomarker Study

My manuscript includes the source files, not a PDF

Barbara Sottero

dept. Clinical and Biological Sciences University of Torino

Barbara Sottero, Simona Gargiulo, Daniela Rossin, Paola Gamba, Giuseppe Poli, Gabriella Testa

HUVEYDA BASAGA, Giuseppe Valacchi, Jose Vina, Valerio Leoni

\section{Submission Files Included in this PDF}

\section{File Name [File Type]}

Cover letter Sottero et al.doc [Cover Letter]

Highlights Sottero et al .doc [Highlights]

Graphical abstract Legend Sottero et al .doc [Graphical Abstract]

Graphical abstract Sottero et al .tif [Graphical Abstract]

Manuscript Sottero et al .doc [Manuscript File]

Table 1 Sottero et al .doc [Table]

Table 2 Sottero et al.doc [Table]

To view all the submission files, including those not included in the PDF, click on the manuscript title on your EVISE Homepage, then click 'Download zip file'. 
Prof. Francesco Galli and Prof. Gabriele Cruciani,

Editors of

"Redox lipidomics: technology, methods, and applications in biology and medicine"

Free Radical Biology and Medicine Special Issue

Turin, February 28, 2019

\section{Dear Editors,}

I am submitting to Free Radical Biology and Medicine (Special Issue: "Redox lipidomics: technology, methods, and applications in biology and medicine") for consideration the review "Omics analysis of oxysterols to better understand their pathophysiological role" (Sottero et al.).

We deem the content of this manuscript of interest for a wide typology of scientists in the area of redox lipidomics. The present manuscript aims to highlight the lipidomics approaches in the study of the association between cholesterol oxidation products and diseases, such as metabolic and neurodegenerative disorders, cardiovascular diseases, and cancer.

The title of the manuscript we had previously indicated was "Oxysterols: analysis and pathophysiological role". As you will notice the title is now different, and also the order of the authors. We hope these changes will not create problems.

The author of the article will be in this order:

- Barbara Sottero, corresponding author (barbara.sottero@unito.it)

- Simona Gargiulo (simona.gargiulo@unito.it)

- Daniela Rossin (d.rossin@unito.it)

- Paola Gamba (paola.gamba@unito.it)

- Giuseppe Poli (giuseppe.poli@unito.it)

- Gabriella Testa (gabriella.testa@unito.it) 
I hereby declare, as corresponding author and on behalf of co-authors that:

1. we don't have conflicts of interest

2. all authors approve the manuscript for submission

3. the manuscript is not currently under consideration elsewhere.

Here you will also find the persons we suggest as Peer Reviewers of the manuscripit:

Prof. Huveyda Basaga

Faculty of Engineering and Natural Sciences, Sabanci University of Istanbul, Turkey huveyda@sabanciuniv.edu

Prof. Jose Vina

Faculty of Medicine, University of Valencia, Spain

jose.vina@uv.es

Prof. Valerio Leoni

Department of Laboratory Medicine, University of Milano-Bicocca, School of Medicine, Hospital of Desio (Milano), Italy

valerioleoni@hotmail.com

Prof. Giuseppe Valacchi

Department of Animal Science, NC State University, Plants for Human Health Institute, Kannapolis, $\mathrm{NC}$

gvalacc@ncsu.edu

Looking forward to hearing from you,

With best regards,

Barbara Sottero 


\section{Highlights}

- Cholesterol is linked to oxidative stress- and inflammation-related diseases

- Enzymatic and non-enzymatic cholesterol oxidation leads to bioactive oxysterols

- Lipidomics is a powerful technique for oxysterol analysis in biological specimens

- Lipidomics data may associate oxysterols with cholesterol-related pathologies 


\section{Graphical abstract legend}

Cholesterol is a fundamental lipid in the development and physiological function of mammals, thus alterations of its plasma and tissue levels, due to incorrect diet or aberrant metabolism, are associated with several chronic diseases, many of which are characterized by activation of oxidative stress and inflammation. As a consequence of cholesterol enzymatic and non-enzymatic oxidation, a wide spectrum of compounds, named oxysterols, are produced. These molecules are provided with powerful biological activities, and are likely the actual mediators of many of the cholesterol pathophysiological effects. Their application as biomarkers in complex biological specimens is therefore gaining increasing attention. For this purpose, the most powerful approach can be offered by highly sensitive and selective lipidomics techniques. 


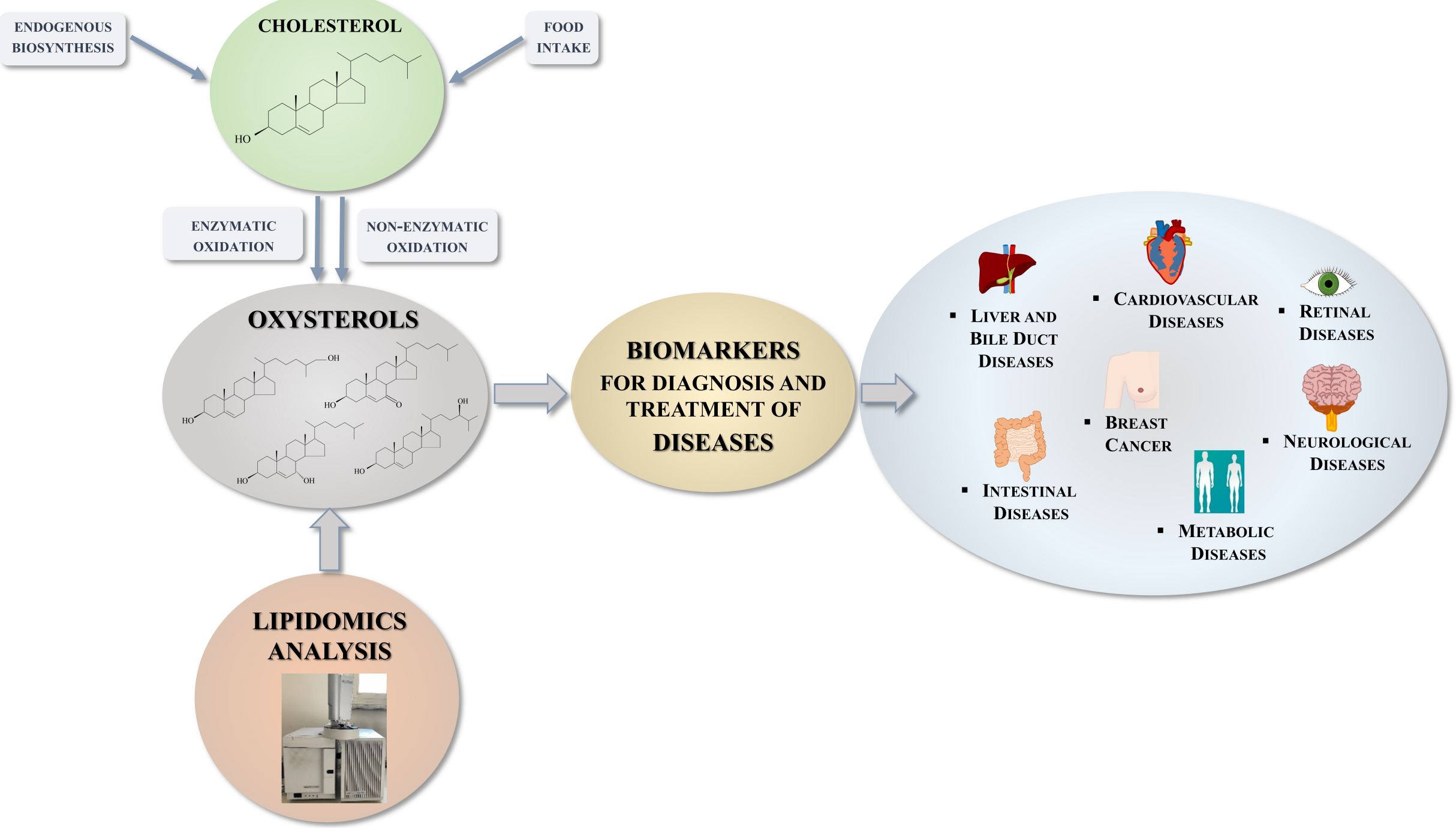




\title{
Omics analysis of oxysterols to better understand their pathophysiological role
}

Barbara Sottero, Simona Gargiulo, Daniela Rossin, Paola Gamba, Giuseppe Poli, Gabriella Testa

Department of Clinical and Biological Sciences, San Luigi Hospital, University of Torino, Italy

Correspondence to: Barbara Sottero, Department of Clinical and Biological Sciences, San Luigi Hospital, University of Torino, Regione Gonzole 10, 10043 Orbassano (Torino), Italy; Phone: +39 0116705444 E-mail: barbara.sottero@unito.it

\begin{abstract}
High amounts of cholesterol have been definitely associated with the pathogenesis of several diseases, including metabolic and neurodegenerative disorders, cardiovascular diseases, and cancer. In all these pathologies the exacerbation of pro-oxidant and inflammatory responses is a consistent feature. In this scenario, species derived from enzymatic and non-enzymatic cholesterol oxidation, namely oxysterols, are strongly suspected to play a primary role. The consideration of these bioactive lipids is therefore helpful in investigating pathological mechanisms and may also acquire clinical value for the diagnosis and treatment of the disease. For this purpose and considering that a great number of oxysterols may be present together in the body, the employment of lipidomics technology certainly represents a powerful strategy for the simultaneous detection and characterization of these compounds in biological specimens. In this review we will discuss the applicability of lipidomics approach in the study of the association between oxysterols and diseases.
\end{abstract}

Keywords: oxysterols, cholesterol, lipidomics, liquid- and gas-chromatography/mass-spectrometry, cardiovascular diseases, neurological diseases, metabolic diseases, cancer, inflammation, oxidative stress 


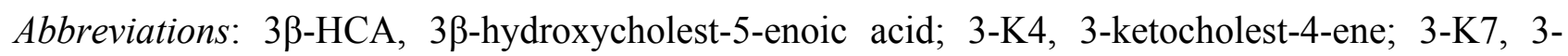

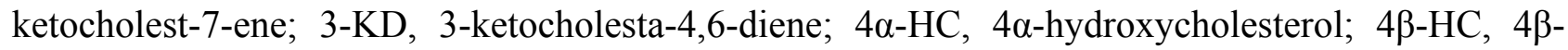

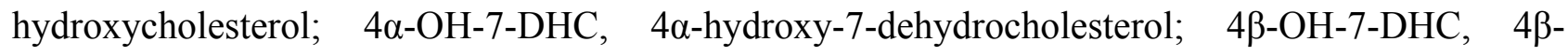
hydroxy-7-dehydrocholesterol; $5 \alpha, 6 \alpha$-EPOX $, \quad 5 \alpha, 6 \alpha$-epoxycholesterol; $\quad 5 \alpha, 6 \beta$-diHC, $5 \alpha, 6 \beta$ -

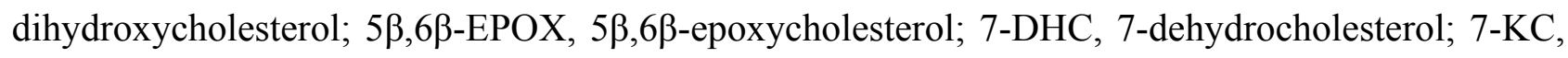

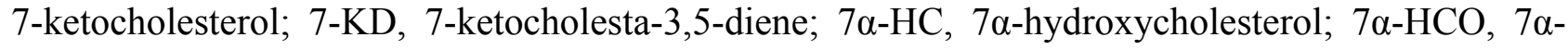

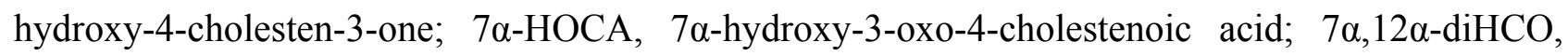

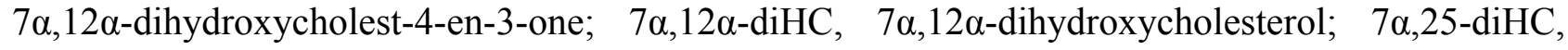

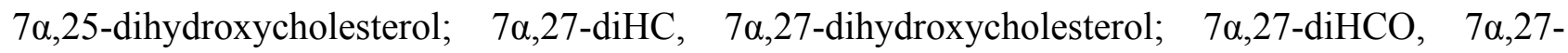
dihydroxycholest-4-en-3-one; 22-HC, 22-hydroxycholesterol; 24S-HC, 24S-hydroxycholesterol; 24-OH-7-DHC, 24-hydroxy-7-dehydrocholesterol; 24-OH-8-DHC， 24-hydroxy-8dehydrocholesterol; 24S,25-EPOX, 24S,25-epoxycholesterol; 25-HC, 25-hydroxycholesterol; 25 OH-8-DHC, 25-hydroxy-8-dehydrocholesterol; 27-HC, 27-hydroxycholesterol; 27-OH-8-DHC, $27-$ hydroxy-8-dehydrocholesterol; $\mathrm{A} \beta$, amyloid $\beta$; $\mathrm{AD}$, Alzheimer's disease; ALS, amyotrophic lateral sclerosis; AMD, age-related macular degeneration; APCI, atmospheric pressure chemical ionization; $\mathrm{BC}$, breast cancer; $\mathrm{BBB}$, blood-brain barrier; $\mathrm{ChEH}$, cholesterol-5,6-epoxide hydrolase; CSF. cerebrospinal fluid; CVD, cardiovascular disease; CTX, cerebrotendinous xanthomatosis; CYP2 $\alpha \mathrm{A} 1$, sterol 27-hydroxylase; DHCEO, 3 $\beta, 5 \alpha$-dihydroxycholest-7-en-6-one; ESI, electrospray ionization; HD, Huntington's disease; LC, liquid chromatography; LXR, liver X receptor; GC, gas chromatography; HPLC, high-performance LC; IR, insulin resistance; MCI, mild cognitive impairment; MetS, metabolic syndrome; MRM, multiple reaction monitoring; MS, mass spectrometry; MS/MS, tandem mass spectrometry; MSdis, multiple sclerosis; MS ${ }^{\mathrm{n}}$, multistage fragmentation; NAFLD, non-alcoholic fatty liver disease; NPC, Niemann-Pick type C disease; OCDO, 6-oxo-cholestan-3 $\beta, 5 \alpha$-diol; PD, Parkinson's disease; PDA, photodiode array; ROS, reactive oxygen species; SLO, Smith-Lemli-Opitz syndrome; SPE, solid phase extraction; TRIOL, cholestane-3 $\beta, 5 \alpha, 6 \beta$-triol; UPLC, ultra-performance LC.

\section{Introduction}


Cholesterol is an essential lipid in mammals, where it represents a main component of cell membranes and a precursor/intermediate for the biosynthesis of a great number of fundamental molecules, namely bile acids, all steroid hormones and vitamin D. Besides its endogenous production, it may derive from the dietary intake of food of animal origin [1].

Cholesterol oxidation, either enzymatic or non-enzymatic (i.e. autoxidation), gives rise to a wide class of compounds, named oxysterols, which are characterized by the presence of one or more oxygen containing functional groups in the sterol ring and/or in the side-chain. Nowadays, a large bulk of literature points to oxysterols as very important molecules in human pathophysiology [1,2]. They are not only involved in some of the cholesterol-dependent metabolic routes (e.g. the bile acid precursors $7 \alpha$-hydroxycholesterol, $7 \alpha-\mathrm{HC}$, and 27-hydroxycholesterol, 27-HC), but also contribute to cholesterol homeostasis by mediating its turn-over in the body (e.g. 24S-hydroxycholesterol, 24S-HC, and 27-HC), or acting as signaling molecules in the regulation of some enzymes responsible for cholesterol synthesis and conversion (e.g. 3-hydroxy-3-methylglutaryl coenzyme A reductase, acyl coenzyme A: cholesterol acyltransferase, neutral cholesteryl ester hydrolase) [3, 4]. Moreover, oxysterols seem to affect some fundamental pathways in embryonic and tissue development, including neurogenesis [4,5], and to contribute to the host defense against viral infections [6].

On the other hand, increasing evidence correlates oxysterols to the onset and progression of several pathologies including cancer and metabolic, neurodegenerative, and cardiovascular diseases. In some cases, inherited abnormalities in cholesterol metabolism are the cause of the pathological condition, but frequently this is the consequence of an exacerbated oxidative stress in which a sustained production of reactive oxygen species (ROS) enhances cholesterol oxidation, and contributes to chronic inflammation [7].

As the consequence of the multiplicity of mechanisms responsible for the oxysterol presence in the body, enzymatic and autoxidative processes plus food intake, oxysterol mixtures, rather than single compounds, are actually found in biological fluids and organs. For this reason, oxysterol characterization appears extremely challenging, but the recent advances in lipidomics point to this approach as a powerful tool for the study of these compounds.

Here we deemed useful to focus on the most recent and interesting literature in which a pathophysiological role of oxysterols is supported by means of lipidomics, highlighting the potential outcomes of their monitoring as biomarkers in the diagnosis and treatment of diseases. 


\section{Oxysterol lipidomics: analytical background}

The interest roused by oxysterols as molecules provided with significant biological activity has led the research effort to develop analytical methods suitable for their characterization, as more indepth overviewed elsewhere in the present special issue.

In this connection, some factors are worth to be considered. Firstly, oxysterol amounts in biological fluids and tissues are usually very low, even in pathological conditions. The employment of advanced liquid chromatography- and gas chromatography-mass spectrometry (LC-MS and GCMS) techniques, in particular the implementation of protocols for analyte derivatization, have much improved oxysterol identification and quantification. Of note, the effectiveness of these procedures for quantitative measurement strictly relies on the proper use of internal standards, such as deuterated oxysterols, otherwise only approximate or semi-quantitative estimates are possible [8]. Moreover, the presence in the biological matrices of several other compounds, in particular high amounts of cholesterol, can be source of errors thus negatively affecting the reliability of oxysterol measurement. Before final determination, specimens should undergo solvent extraction and solid phase extraction (SPE), thus enabling isolation of oxysterols from other species, including lipids, and at the same time favoring their enrichment in the samples. Of note, analyses might include cholesterol whose comparison to oxysterols could be informative to understand the extent of oxidative modifications. On the other hand, cholesterol is easily prone to autoxidation and its presence may lead to overestimation of oxysterol amounts. To avoid that, the addition of antioxidants (e.g. butylated hydroxytoluene) is absolutely required and samples must be always collected, stored and processed at cold temperature, with limited exposition to light and air. Moreover, since biological oxysterols mainly exist as fatty acid esters, saponification by means of alkaline hydrolysis is often included for a reliable quantification of their total amount. Of note, this step represents another important cause of oxidative modification or decomposition that could affect the final result [9-11].

Despite all these limitations, a broad range of oxysterols together with other steroid compounds have been reported to be successfully analyzable in a single sample by high-performance LC(HPLC)- and GC-MS, after optimization of the hydrolysis and separation procedures [12]. Other novel methodologies for sample preparation have also been presented, for example an automated filtration/filter backflush SPE for the separation of 24-, 25- and 22-hydroxycholesterol (22-HC) [13].

Interestingly, alternative GC- and LC-MS techniques have been proposed for oxysterol evaluation, including ultra-performance LC (UPLC)-ion mobility-time-of-flight MS (IM-TOFMS) [14]. 


\section{Application of lipidomics to the study of oxysterols in human pathophysiology}

In the last two decades, an increasing literature has reported the use of the lipidomics approach to study the role of oxysterols in human pathophysiology (Fig. 1). Most investigations strengthened the feasibility of oxysterol measurement as indicator of illness, both rare diseases caused by inherited errors in cholesterol metabolism, and widespread acquired chronic diseases often induced by an unhealthy lifestyle. Of note, most of these pathological conditions share as main causes the imbalance of the physiological redox equilibrium together with a sustained inflammatory response. Although very promising, the application of oxysterol analysis to the clinical practice still shows some critical aspects. Data are sometimes inconsistent, in part because of the great individual variability of factors like age, race, gender. life-style. Analytical artifacts may also derive from sample handling and processing, since often laboratories do not share the same procedures.

Further, results also differ depending on whether total or free (i.e. non esterified) oxysterols are considered. Of note, since esterification to fatty acids is presumed to be a mechanism neutralizing biological activity of cholesterol [3], and likely of oxysterols, evaluation of the free form could be more representative of pathogenic conditions.

In table 1 and table 2 are reported the main oxysterol determinations accomplished in human and animal specimens, respectively. 


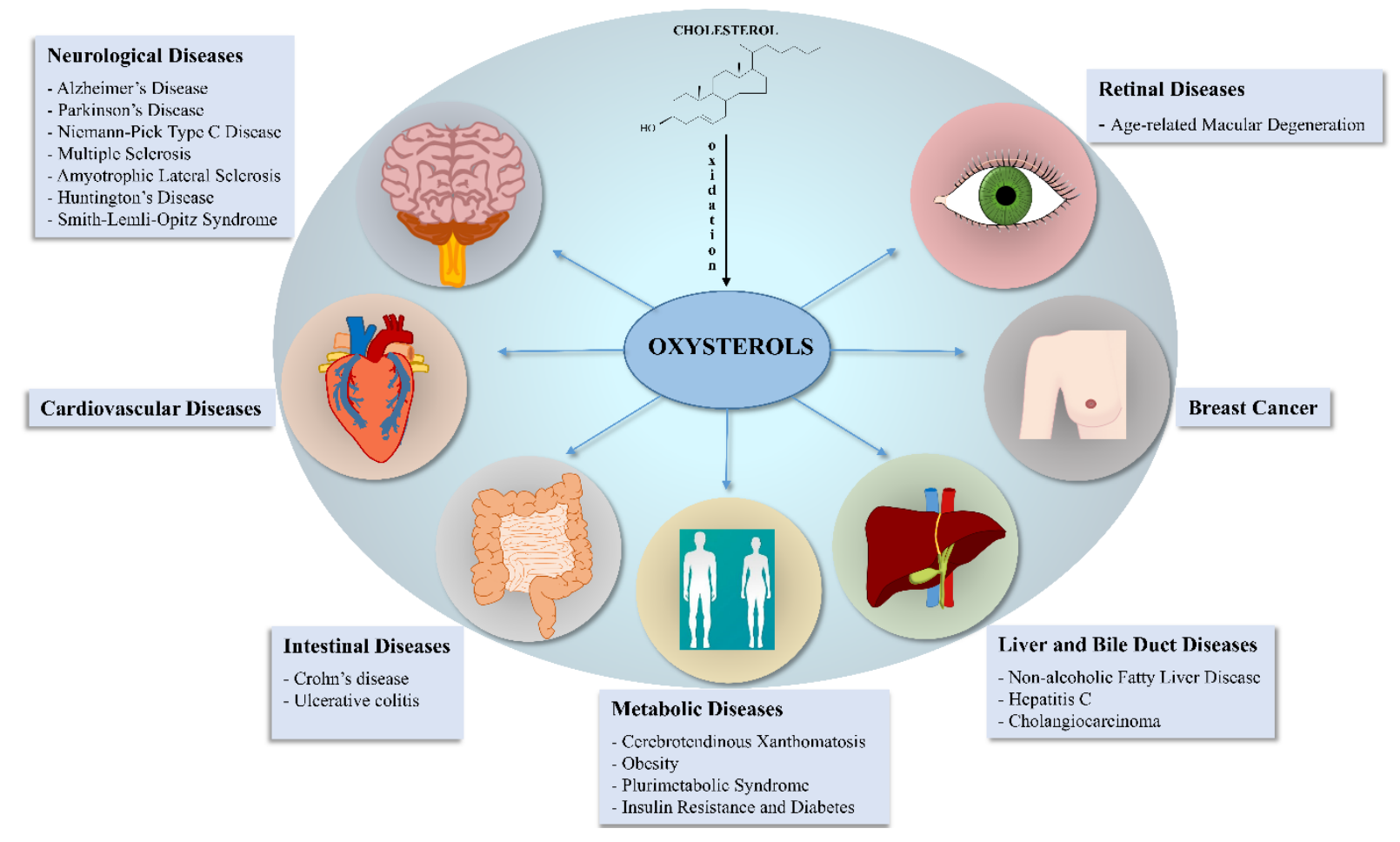

Fig. 1. Association between oxysterols and pathologies, suggested by lipidomics analyses of biological specimens.

\subsection{Oxysterols and Cardiovascular Diseases}

Hypercholesterolemia has been implicated in the pathogenesis of atherosclerosis, and in particular LDL cholesterol has been considered as a primary risk factor for cardiovascular diseases (CVD). Of note, oxidation of these particles generates several reactive molecules that contribute to vascular cell dysfunction by promoting oxidative stress and inflammation. Among them, oxysterols have consistently shown to contribute to the various steps of atheroma development [15].

In consideration of that, at the end of ' 90 s and in the first decade of 2000 s great research effort was devoted to oxysterol evaluation in specimens of animal and human origin, mainly blood and blood vessels, as extensively described in still relevant reports. [3, 16-18]. Some of these investigations were achieved employing LC- and GC-MS.

Despite some discrepancies in the measured oxysterol contents, several data concur in confirming the presence of these compounds in CVD. A rapid protocol using LC-tandem MS (MS/MS), combined with an atmospheric pressure chemical ionization (APCI) source operating in the positive mode, was developed for the quantification of free oxysterols (i.e. 7-ketocholesterol, 7-KC, 


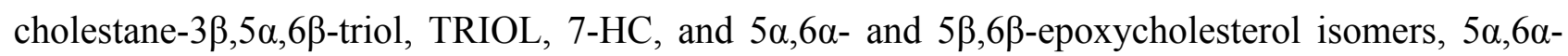
EPOX and $5 \beta, 6 \beta$-EPOX) in human plasma of healthy middle-aged volunteers, and it has been also successfully applied to demonstrate accumulation of cholesterol oxides in carotid plaques. This procedure has been improved by reducing the complex sample pretreatment to a single protein precipitation and concentration step [19].

The content of enzymatic side-chain oxidized oxysterols in the arterial intima was compared to their concentrations in the corresponding plasma samples of individuals with or without severe peripheral artery disease. Results from GC-MS determination showed that 24S-HC and mostly 27-HC, were significantly abundant in the arteries with atherosclerotic plaques, although their blood levels did not show any significant difference between patients and controls. The evidence is consistent with a major endothelial permeability in the subjects who develop atheroma. Remarkably, tissue amounts of the two oxysterols significantly correlated with plasma level of the inflammation index Creactive protein [20].

Another investigation worth of mention is a HPLC-MS/MS analysis, that established for the first time a significant elevation of serum $24 \mathrm{~S}-\mathrm{HC}$ in patients with hypercholesterolemia of genetic origin. Moreover, highest level of 24S-HC corresponded to an increase in the carotid intima media thickness of the patients. Other two intermediates of bile acid synthesis, 27-HC and 7 $\alpha$-hydroxy-4-

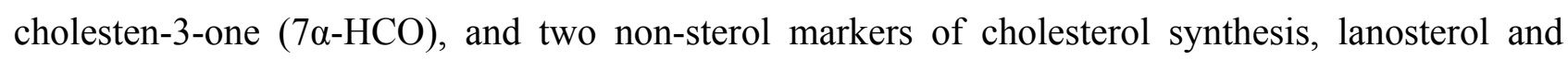
desmosterol, were also present at high amounts, consistent with hepatic overproduction of cholesterol [21].

Recently, much attention has been paid to the potential application of oxysterols as indicators of the efficacy of lifestyle interventions and therapies potentially useful to counteract atherosclerosis progression. For instance, detection of oxysterols by GC-MS was employed to evaluate the effect of aerobic exercise training in dyslipidemic mice [22], and of antioxidant supplementation in hamsters fed hypercholesterolemic diets [23]. In hypercholesterolemic mice, LC-APCI-MS oxysterol evaluation highlighted the potential benefit of phytosterol supplementation of the maternal diet in offspring from hypercholesterolemic mice. ApoE $\mathrm{E}^{-/-}$mothers fed a high cholesterol diet and their pups exhibited increased serum 7 $\alpha-\mathrm{HC}, 7 \beta-\mathrm{HC}, 7-\mathrm{KC}, 24 \mathrm{~S}-\mathrm{HC}$, and 25-hydroxycholesterol (25$\mathrm{HC}$ ), but not 27-HC, compared with the $\mathrm{ApoE}^{-/-}$chow group; phytosterol intervention reduced oxysterol concentrations in both dams and their offspring upon. Overall, the results demonstrate that a hypercholesterolemic maternal environment during pregnancy and lactation is able to affect oxysterol status in offspring, and point to phytosterols as a suitable CVD risk-reduction strategy either in hypercholesterolemic mothers and in their newly weaned offspring [24]. 
Lastly, a LC-MS/MS multiple reaction monitoring (MRM) detection of circulating 24S-HC, 25-HC, $27-\mathrm{HC}, 7 \beta-\mathrm{HC}$ and $7-\mathrm{KC}$ proved the capability of simvastatin to reduce oxysterols of both enzymatic and non-enzymatic origin, and not only cholesterol. In particular, the blood level of oxysterols $7-\mathrm{KC}, 7 \beta-\mathrm{HC}$ and $25-\mathrm{HC}$ was brought back to the normal range, even after normalization to total plasma cholesterol, thus suggesting antioxidant properties of the drug beside its cholesterollowering action [25].

\subsection{Oxysterols and Metabolic Diseases}

Metabolic disorders, characterized by abnormalities in cholesterol metabolism, are currently among the major health concerns in the world. Oxysterols are highly suspected to participate in these pathologies as well [26].

\subsubsection{Cerebrotendinous Xantomathosis Syndrome}

The pathogenetic importance of oxidized intermediates was initially highlighted by the study of pathologies due to inborn errors of genes involved in cholesterol synthesis and conversion. This is the case of cerebrotendinous xanthomatosis (CTX), a disease caused by a deficiency of sterol 27hydroxylase (CYP27A1), responsible for decreased synthesis of bile acids, excessive production of cholestanol with its accumulation in tissues, progressive neurological dysfunction, premature atherosclerosis, and cataract.

Besides the evaluation of the CYP27A1 product 27-HC, advanced LC- and GC-MS allowed the recognition of other oxysterols associated with CTX. An isotope dilution LC-electrospray ionization (ESI)-MS/MS methodology utilizing keto derivatization was developed for the simultaneous quantification of 3-oxo bile acids precursor in plasma of CTX patients, providing a sensitive biochemical test with diagnostic value [27]. Similarly, the presence in CTX plasma of high concentrations of the bile acids' precursors $7 \alpha-\mathrm{HC} / 7 \alpha-\mathrm{HCO}$ and $7 \alpha, 12 \alpha$-dihydroxycholesterol

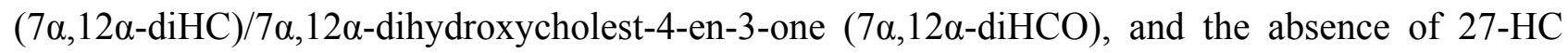
and $3 \beta$-hydroxycholest-5-enoic acid (3 $\beta$-HCA), indicating a dysfunctional bile acid biosynthesis, was assessed by LC-MS quantification of the isotope-labeled charge-tagged derivatives [28]. A similar charge-tagging approach, in this case implying an enzyme-assisted derivatization step, has been utilized for the identification of over 50 cholesterol metabolites and precursors in the brain and 
circulation of CYP27A1 lacking mice, helping in the elucidation of the metabolic pattern that characterizes CTX disease [29].

\subsubsection{Obesity, Metabolic Syndrome and Insulin Resistance}

Oxysterols are also emerging as key-players in the genesis of those metabolic disorders commonly ascribed to incorrect lifestyle (mainly overnutrition and sedentary behavior), including obesity and metabolic syndrome (MetS).

A typical feature in these morbidity states is a dyslipidemic condition with elevated levels of LDL cholesterol, total cholesterol and triglycerides, as well as a decrease in HDL cholesterol concentration. Lipid abnormalities induce oxidative stress, which in turn results in a state of lowgrade chronic inflammation with deregulated production of cytokines, adipokines and chemokines, thus exerting harmful effects within adipose tissue and liver, and contributing to the development of insulin resistance (IR) and eventually diabetes [30].

In this context, it might be postulated that an extensive formation of bioactive oxysterols occurs and amplifies the inflammatory response. In agreement with that, the accumulation of two free-radical derived oxysterols, 7-KC and 7 $\beta-\mathrm{HC}$, was detected by GC-MS, in adipocytes isolated from obese patients with type 2 diabetes; the first compound was proven to act as an adipokine modulator in adipose-derived stem cells [31]. Similarly, in diet-induced obese mice, GC-MS analysis confirmed an elevation of several oxysterols, mainly of non-enzymatic origin, in the plasma, liver and adipose tissue [32]. A HPLC-APCI-MS method enabled the simultaneous quantification of 11 oxysterols and ceramides, dihydroceramides, endocannabinoids and $\mathrm{N}$-acylethanolamines in the liver and adipose tissue of diet-induced obese mice. In this case, however, the tissue levels of oxysterols were not markedly affected by the high fat diet, with the exception, in the liver, of a significant decrease

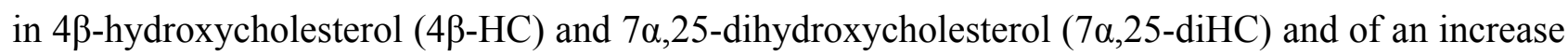
in $7 \alpha-\mathrm{HCO}$ and $27-\mathrm{HC}$, both of which are key intermediates in the synthesis of bile acids, probably reflecting the capability of dietary lipids to differently affect several pathways involved in metabolic sterol oxidation [33].

Although experimental investigations on in vitro and in vivo models of obese-associated illness are strongly in favor of oxysterol effectiveness in modulating the pathological process by interaction with several molecular factors [34], their actual presence in biological specimens has not yet been consistently defined. The high variability of the available data might depend on gender, age and life habits, and makes oxysterol relevance as markers in the assessment of metabolic disorders still questionable. 
A gender-related distribution of circulating oxysterols in patients with obesity and MetS was reported after isotope dilution GC-MS, consistent with the established sexual dimorphism in lipid metabolism. In male patients, significant changes were observed in $4 \alpha$ - and $4 \beta$-HC levels only. In females, significant changes were also observed for other oxysterols of both enzymatic and nonenzymatic origin. In particular, higher levels of $7 \beta-\mathrm{HC}$ and TRIOL were found in female patients with MetS compared to healthy controls or obese patients. Interestingly, a significant correlation was observed between $4 \beta-\mathrm{HC}$ and saturated and mono-unsaturated fatty acids, both in males and females, suggesting a common regulation of different lipogenic pathways [35].

On the other hand, an observational study conducted over a one-year period on 30 postmenopausal women, showed no association between body mass index (BMI) and the serum levels of $7 \alpha-\mathrm{HC}$, 24S-HC, 25-HC, and 27-HC, detected by LC-MS analysis [36].

In a cohort study conducted in adolescent girls, serum concentrations of 7-HC isomers and 7-KC increased and positively correlated with BMI, insulin, LDL cholesterol and apolipoprotein B [37]. An elevation of 7-KC was recognized in the blood of hypercholesterolemic and diabetic patients relative to controls, $7 \alpha$ - and $7 \beta-\mathrm{HC}$ were specifically higher in diabetic blood, and $\alpha$-EPOX in hypercholesterolemic patients [38]. Considering that in both studies 19-hydroxycholesterol was employed as internal standard for oxysterol measurement by GC-MS, data might need confirmation by means of quantitative isotope dilution LC- and GC-MS.

In this regard, very recently, a LC-MS/MS protocol including deuterated oxysterols as internal standards and N,N-dimethylglycine derivatization was applied to compare the plasma oxysterol level among healthy subjects and type 1 and type 2 diabetes mellitus patients, reporting 7-KC and TRIOL elevation in association with disease, particularly with type 2 diabetes [39].

The potential use of oxysterols as markers of IR would be corroborated by the results from a LCMS/MS analysis of the sera of hypercholesterolemic patients with non-alcoholic fatty liver disease (NAFLD), a condition that shares many features with MetS. In NAFLD patients, the concentrations of $4 \beta-\mathrm{HC}, 25-\mathrm{HC}$, and $27-\mathrm{HC}$, expressed as ratios to cholesterol content, were significantly elevated compared to controls. Of note, these oxysterols are ligands for the liver X receptor $\alpha$ (LXR $\alpha$ ), a key factor in the regulation of lipid metabolism. As regards the others LXR $\alpha$ ligands, 24S-HC level in NAFLD patients was not significantly different from controls and only trace amounts of 22R-HC and 24S,25-epoxycholesterol (24S,25-EPOX) were detected [40].

\subsection{Oxysterols and Neurological Diseases}


The mammalian central nervous system is particularly rich in cholesterol, thus even oxysterols are likely present in measurable amounts and seem to affect brain functions. For this reason, oxysterol profile in biological matrices is extensively examined to elucidate neurological disorders.

Some oxysterols derive principally from enzymatic processes, that take place in the brain, as for 24S-HC, also known as cerebrosterol, and for 7 $\alpha$-hydroxy-3-oxo-4-cholestenoic acid (7 $\alpha$-HOCA), a 27-HC metabolite in neurons, which are in fact the effectors of physiological cholesterol efflux from the brain to the circulation [41].

In addition, many oxysterols are generated following oxidative stress, to which the brain is particularly exposed being this organ strictly dependent on oxidative metabolism [42]. Alternatively, oxysterols produced in other organs, either enzymatically or as the consequence of systemic ROS overproduction, can flow in the circulation and reach the brain by crossing the bloodbrain barrier (BBB) [41].

As a consequence of exchange through $\mathrm{BBB}$, oxysterols variation in the peripheral circulation may reflect changes in their brain content and vice versa. In this connection, differences in the blood concentrations, between jugular and forearm veins, of eighteen oxysterols, five cholestenoic acids and three cholenoic acids were measured by LC- and GC-MS. The data showed that 24S-HC and, to a lesser extent, $7 \beta$-HC, 7-KC, 5 $\alpha$-hydroxy-6-oxocholesterol and $7 \alpha-\mathrm{HOCA}$, were exported from the brain, whereas 27-HC was imported into the brain [43].

In biological specimens, and particularly in cerebrospinal fluid (CSF), the ratio may be assumed as a meaningful indicator of nature and extent of the events associated with neurodegeneration. 24Hydroxycholesterol originates almost exclusively in the brain whereas 27-HC originates mainly in several other organs and is metabolized in the brain by the enzyme CYP7B1. A deviation from the physiological $24 \mathrm{~S}-\mathrm{HC} / 27-\mathrm{HC}$ ratio indicates a loss of cerebral enzymatic activity consequent to neuronal death, or alteration in oxysterol release to CSF due to disruption of the blood-CSF barrier or BBB [44]. In this regard, the benefit of lipidomics is evident, since it allows the simultaneous detection of these two molecules in the same sample.

Therefore, the major attention of analytical research was paid to 24S-HC, 27-HC and, to a lesser extent, to $7 \alpha$-HOCA, although other oxysterols were also considered as indices of neurological disturbances in diverse types of biological specimens [45-47].

Recently, a novel on-line SPE-LC-ESI-tandem MS (MS/MS) assay provided the simultaneous quantification of free cholesterol and 34 of its metabolites, including 17 free oxysterols, in plasma and CSF of patients having BBB disturbances. Among the main brain cholesterol oxides, 24S-HC and $27-\mathrm{HC}$ could not be detected in CSF, whereas $7 \alpha-\mathrm{HOCA}$ was quantified showing a concentration relatively higher than that of the other cholesterol metabolites; moreover, a 
correlation between $7 \alpha$-HOCA level and the degree of BBB dysfunction was also confirmed, suggesting the potential application of this molecule as a marker of BBB damage [48].

Defects of cholesterol homeostasis in the adult brain are linked to neurodegenerative diseases like Niemann-Pick type C (NPC) disease, Alzheimer's disease (AD), Parkinson's disease (PD), Huntington's disease (HD), multiple sclerosis (MSdis), and amyotrophic lateral sclerosis (ALS) in which oxidative stress and inflammation represent driving forces for the progressive degeneration and death of neurons [42].

In this connection, a very recent work provides solid support to the relationship between oxysterols and neuroinflammation. The levels of over 10 oxysterols were analyzed by means of HPLC-MS, operating in the positive mode with APCI source, in the microglia BV2 cells after treatment with LPS. Surprisingly, at prolonged incubation periods, LPS-activation differently affected the amounts of cell oxysterols. In particular, the ones oxidized on the sterol backbone increased, and the ones oxidized on the side chain decreased (e.g. the enzymatic products $25-\mathrm{HC}$ and $27-\mathrm{HC}$ ); both $5 \alpha, 6 \alpha-$ and 5 $\beta, 6 \beta$-EPOX did not change. This evidence strongly indicates that ROS overproduction after inflammatory stimuli would sustain non-enzymatic cholesterol oxidation, but, at the same time, it would alter the expression and/or activity of the oxysterol-metabolizing enzymes, as further investigated in the same study. Some similarities in the oxysterol pattern after LPS-treatment were observed also in co-culture of primary microglia and astrocytes, but not in mice brain. In this organ, sterol backbone oxidized species decreased suggesting that other eventually protective mechanisms could occur in case of systemic inflammation [49].

\subsubsection{Alzheimer's Disease}

The link between AD and oxysterols has been definitely recognized. Alteration in the biological levels of these compounds would be not only the consequence of the cerebral derangement associated with the disease, but may also contribute to its onset and progression, since oxysterols have been proven to be mediators of several molecular pathways underlying AD ethiopathology [50].

In a populations of patients with memory complaints and identified as probable AD on the basis of their CSF amyloid $\beta 42$ (A $\beta 42)$ and total tau levels, the CSF levels of both 24S-HC and 27-HC, determined through isotope dilution-MS, were higher than in the control-like group, and showed a positive correlation with white matter hyperintensities, a hallmark of demyelination; on the contrary, both oxysterols were reduced in the plasma of AD-like group compared to control-like 
group. The data may reflect an imbalance in brain cholesterol homeostasis with consequent impaired myelination [51].

A systematic analysis of oxysterols, of both enzymatic and non-enzymatic origin, has been performed by GC-MS measurement in post-mortem brains of AD patients at different stages of the disease. Interestingly, most of the oxysterols included in the study (i.e. 25-HC, 27-HC,7-KC, 4 $\alpha-$ $\mathrm{HC}, 4 \beta-\mathrm{HC}, 7 \alpha-\mathrm{HC}, 7 \beta-\mathrm{HC}, \alpha-\mathrm{EPOX}$ and $\beta$-EPOX) increased during disease progression, this increment becoming markedly significant in late stage AD. On the contrary, 24S-HC amount in early stage $\mathrm{AD}$ was similar to that of control brains, whereas it was significantly decreased at advanced disease stages, likely reflecting a selective loss of neuronal cells expressing the cholesterol 24-hydroxylase in the late AD [52].

Other studies focused on the possible relationship between oxysterols and the cognitive decline that characterize AD patients. Plasma levels of $27-\mathrm{HC}, 24 \mathrm{~S}-\mathrm{HC}, 7 \alpha-\mathrm{HC}$ and $7 \beta-\mathrm{HC}$ were quantified by HPLC-MS in subjects diagnosed as suffering from mild cognitive impairment (MCI), namely the pre-clinical stage of AD. Compared to controls with normal cognition, only 27-HC was significantly higher in MCI patients. Of note, this oxysterol not only was significantly associated with MCI, but it also positively correlated with the levels of the neurotoxic A $\beta 1-42$ and $A \beta 1-40$ peptides [53].

Eight sterols were detected by HPLC-MS coupled to multivariate data analysis in scalp hair samples of women including MCI, AD and control subjects. Both $7 \alpha-\mathrm{HC}$ and $7 \beta-\mathrm{HC}$ increased in patients, but in particular significantly higher $7 \beta-\mathrm{HC} /$ cholesterol ratio was observed in the presence of cognitive impairment (MCI and $\mathrm{AD}$ ), thus pointing to this ratio as a predictive biomarker of $\mathrm{AD}$. As far as we know, this is the only work in which hair specimens have been used for oxysterol assessment and, although interesting, the procedure likely need further validation [54].

\subsubsection{Parkinson's Disease}

Several in vitro reports suggest the involvement of oxysterols in the Parkinson's pathology, to which they may contribute causing $\alpha$-synuclein aggregation and destruction of dopamine containing neurons. Nevertheless, there are some prospective clinical investigations from which negative or no correlation emerged between Parkinsonism and oxysterol content [55].

A possible explanation for such conflicting results may reside in the use of blood as specimen for oxysterol characterization. For example, 27-HC and 24S-HC measurement by isotope dilution-MS revealed no differences in the plasma concentrations of these compounds in PD patients with 
different disease duration; on the contrary, when analyzing CSF, both 27-HC and 24S-HC exhibited concentrations above the cut-off level in $10 \%$ of the patients, indicating a possible blood-CSF barrier damage in connection with the pathology, and in particular 24S-HC significantly correlated with the duration of the disease [56,57].

Supporting the actual occurrence of an abnormal oxysterol profile in PD is a very interesting report on the screening by lipidomics techniques of 200 lipid species (including sphingolipids, glycerophospholipids and cholesterol species) in the visual cortex of PD patients. The GC-MS analysis showed that 6 out of 7 oxysterols of both non-enzymatic and enzymatic origin (i.e. $7 \alpha-\mathrm{HC}$, $7 \beta-\mathrm{HC}, 5 \beta, 6 \beta-\mathrm{EPOX}, 7-\mathrm{KC}, 24 \mathrm{~S}-\mathrm{HC}$ and $27-\mathrm{HC}$ ) selectively increased in PD tissue compared to controls. Moreover, these variations appeared to correlate with the changes in the expression of genes involved in cholesterol metabolism and oxidative stress response, that were observed in the same samples by quantitative polymerase chain reaction [58].

\subsubsection{Niemann-Pick Type C Disease}

Niemann-Pick type $\mathrm{C}$ disease is a rare autosomal lipid storage disorder characterized by progressive neurological deterioration with challenging diagnostic procedures since its clinical presentation is variable and non-specific. Improvement in GC- and LC-MS/MS technologies with different derivatization procedures allowed the detection of 7-KC and TRIOL. These two compounds are likely formed non-enzymatically as result of an excessive oxidative attack of cholesterol accumulated in the viscera cells of NPC patients [59]. Of interest, although these oxysterols are indicated as reliable plasma biomarkers of NPC disease, their quantification may sometimes lead to false results, especially in the presence of cholestasis or variant biochemical phenotypes [60-62]. Very recently, the development of a methodology based on charge-tagging LC-MS with multistage fragmentation $\left(\mathrm{MS}^{\mathrm{n}}\right)$ allowed the identification in plasma from NPC patients of unusual oxysterols having 7-oxo and $3 \beta, 5 \alpha, 6 \beta$-trihydroxy functions, which are likely intermediate of the conversion of 7-KC and TRIOL to bile acids. Thus, also these metabolites are worth of consideration in the clinical assessment of NPC disease, and their quantification in this context needs further validation [63].

\subsubsection{Multiple Sclerosis}


Recently, attention has been paid to the possible relationship between oxysterols and the onset of multiple sclerosis (MSdis). In human specimens, mainly the levels of side-chain oxysterols appeared to be altered, although conflicting results have been reported so far.

A derangement of oxysterol network was observed by stable isotope dilution LC-APCI-MS in subjects with relapsing-remitting MSdis and progressive MSdis. Compared to healthy controls, in all patients there was a decrease in the levels of the enzymatic products $7 \alpha-\mathrm{HC}, 24 \mathrm{~S}-\mathrm{HC}$ and $27-$ $\mathrm{HC}$, which presumably reflects changes in cholesterol metabolism in periphery as well as in brain, due to neurodegeneration. An increase in 7-KC was found only in progressive MSdis patients compared with relapsing-remitting MSdis patients, thus indicating a sustained oxidative stress, which promote neurodegeneration in the progressive form [64].

In another paper, LC coupled to APCI-MS in series with photodiode array (PDA) for oxysterol and cholesterol detection respectively, showed lower plasma levels of $27-\mathrm{HC}$ and $7 \alpha-\mathrm{HC}$ in MSdis patients versus controls, even when normalized to cholesterol, while other oxysterols (i.e. 7-KC, 24S-HC and 25-HC), cholesterol and 25-hydroxy-vitamin D did no show any significant variation [65].

Moreover, in a mouse model of MSdis, the disease was apparently accompanied by a decrease of $5 \alpha, 6 \beta$-dihydroxycholesterol ( $5 \alpha, 6 \beta$-diHC), 7-KC and 24S,25-EPOX, and by an increase of 7 $\alpha, 25-$ di-HC, as assessed by LC-MS in the brainstem of animals sacrificed at different stages of the disease. In particular, $7 \alpha, 25$-di-HC was proposed to contribute to neurodegeneration by promoting inflammatory responses [49].

\subsubsection{Amyotrophic Lateral Sclerosis}

Amyotrophic lateral sclerosis (ALS) is a non-demyelinating neurodegenerative disease in adults. Oxidative stress, neuroinflammation and disturbance in cholesterol homeostasis have been supposed to be critical in the occurrence of this pathology, which in the $10 \%$ of cases also shows genetic mutations [66]. Although certain cholesterol oxides are potentially involved in ALS, for example. $25-\mathrm{HC}$ and $27-\mathrm{HC}$, it is not yet clear whether they could be used as biomarkers, since analyses, mainly carried out in blood and CSF by LC-MS, produced conflicting results [66-68]. It could not be excluded that species less frequently analyzed might be useful for this purpose. In fact, the measurement of more than 40 sterols by LC-MS in not hydrolyzed samples revealed that, when normalized to cholesterol, the CSF amount of 3 $\beta, 7 \alpha$-dihydroxycholest-5-en-26-oic acid, along with its precursor $3 \beta$-hydroxycholest-5-en-26-oic acid and its product $7 \alpha$-hydroxy-3-oxocholest-4- 
en-26-oic acid, were decreased in ALS patients compared with healthy controls, as well as the serum level of $27-\mathrm{HC}$, which is the immediate precursor of $3 \beta$-hydroxycholest-5-en-26-oic, in agreement with defective cholesterol metabolism in ALS brain [69].

\subsubsection{Huntington's Disease}

Huntington's disease (HD) is an autosomal dominant, progressive neurodegenerative disease whose pathogenesis might primarily involve lipid oxidative stress, as suggested by GC-MS quantification in post mortem human brain tissue of $7 \beta-\mathrm{HC}, 7-\mathrm{KC}, 24 \mathrm{~S}-\mathrm{HC}, 27-\mathrm{HC}$ and other sterols. Compared to control tissue, 24S-HC and the enzyme responsible for its synthesis, cholesterol 24-hydroxylase, showed a net decrease, while $27-\mathrm{HC}$ concentration was increased mostly in the HD putamen; in the same region, a rise of the free-radical generated oxysterols $7-\mathrm{KC}$ and $7 \beta-\mathrm{HC}$ was also observed. $[70]$.

\subsubsection{Smith-Lemli-Opitz Syndrome}

The Smith-Lemli-Opitz (SLO) syndrome is a disorder caused by mutations in gene encoding for the cholesterol biosynthesis enzyme $3 \beta$-hydroxysterol- $\Delta$-(7)-reductase, which lead to elevated level of 7-dehydrocholesterol (DHC) and reduced level of cholesterol in all biological tissues. It is characterized besides other symptoms by prenatal and postnatal growth retardation, microcephaly, and moderate to severe intellectual disability. Of note, 7-DHC has been recognized to be highly oxidizable and several oxysterols may derive from its radical or enzymatic oxidation, as observed by means of LC-MS analyses of fluids and tissues from SLO patients and mouse models [71-75].

\subsection{Oxysterols and Retinal Diseases}

Cholesterol accounts for $2 \%$, by weight, of the retina and rod outer segment membranes, where it can also accumulate once delivered from circulating LDL. Eye exposure to sunlight makes this lipid highly susceptible to oxidation. It is therefore conceivable that oxysterols concur in the pathogenesis of age-related diseases of the retina [7,76].

The fact that free radical-mediated photoxidation of cholesterol in the retina leads to in situ formation of oxysterols was sustained by a LC-MS analysis of photodamaged rat retina, where 7- 
$\mathrm{KC}, 7-\mathrm{HC}$ and 5,6-EPOX isomers, but also their precursors $7 \alpha$ - and $7 \beta$-hydroperoxycholesterol, appeared to be present at much greater amounts than in non-photodamaged specimens. Moreover, 7-KC was shown by immunohistochemistry to accumulate in the ganglion cell layer, the photoreceptor inner segments and the retinal pigment epithelium, where it may exert cytotoxic effects contributing to photoreceptors degeneration [77].

It cannot be excluded that abnormalities in cholesterol intake and metabolism, rather than its extensive photoxidation, could be determinant events for retinopathy. For example, it was found out by LC-MS quantification that a $2 \%$ cholesterol-enriched diet administered to rabbits for 12 weeks caused an accumulation in the animal retina of cholesterol, and specifically of its metabolites 27$\mathrm{HC}, 22-\mathrm{HC}$, and 24-HC, together with structural and morphological changes relevant to age-related macular degeneration (AMD) [78].

Circulating oxysterols have been considered as possible biomarkers in the clinical assessment of AMD: LC-MS/MS oxysterol profiling in human peripheral blood monocytes and in human plasma allowed to discriminate between age-dependent and disease-dependent changes in their content. Although age-associated alterations in oxysterol signatures emerged also in healthy humans, likely reflecting changes in cholesterol homeostasis, only plasma $24-\mathrm{HC}$ among all the analytes (i.e. $4 \beta$ $\mathrm{HC}$, 7-KC, TRIOL, 24-HC, and 27-HC) would differentiate AMD from physiologic aging, even after normalization to total plasma cholesterol, thus highlighting its diagnostic value [79].

However, a more exhaustive update by means of advanced lipidomics analyses in humans aimed to clarify oxysterol involvement in AMD and other eye disease still appears necessary.

\subsection{Oxysterols and Cancer}

Oxysterols possess mutagenic, genotoxic and pro-proliferative activities, as extensively confirmed in different animal and cell models, and are, in fact, associated with the carcinogenesis in different organs including colon, lung, pancreas, liver, and bile ducts. In consideration of that, the strongly suspected relationship between hypercholesterolemia and cancer likely depends on the formation of cholesterol oxides [80,81]. On the other hand, by inducing early inflammatory reactions, citotoxicity and apoptotic death, oxysterols might also counteract cancer growth, suggesting that their pro-tumoral and anti-tumoral properties would largely depend on the cell type, and also on the extent of the oxidative redox imbalance underlying the various steps of tumor progression [82]. 
Although there is a large body of experimental evidence supporting their role as oncomediators, data about their content in cancer bearing animal and particularly in humans are still too few to draw definitive statements.

\subsubsection{Breast Cancer}

The similarities between some oxysterols (e.g. 27-HC, 25-HC, both recognized as tumor promoters) and sexual hormones [80] addressed most of the research interest to their evaluation in the progression of hormone sensitive tumors, in particular in response to pharmacological or surgical interventions.

An example is the work of Dalenc and collaborators, where the detection of 11 oxysterols by GCMS was conducted in the serum of breast cancer $(\mathrm{BC})$ patients to evaluate the therapeutic efficacy of Tamoxifen, a selective estrogen receptor modulator, or of alternative aromatase inhibitors, for the treatment of this tumor. The observed decrease, after 28 days of Tamoxifen treatment, of 25-HC serum levels would sustain, according to the authors, the anti-tumoral activity of this drug. Notably, the initial concentration of $25-\mathrm{HC}$ was significantly greater in the patients undergoing treatment for a metastatic disease than in those under adjuvant treatment, suggesting that $25-\mathrm{OH}$ increase could be a metabolic index of BC aggressiveness. Conversely, the levels of 27-HC significantly increased in response to aromatase inhibitors, but not after Tamoxifen. 5 $\beta, 6 \beta$-EPOX also increases only following therapy with aromatase inhibitors, likely because of the ability of these drugs to induce oxidative stress. Moreover, the same study suggested the use of 5,6-EPOX sulfates as biomarkers of Tamoxifen therapy [83]. These compounds are in fact supposed to be induced by Tamoxifen treatment by inhibition of cholesterol-5,6-epoxide hydrolase $(\mathrm{ChEH})$, and to contribute to the drug anti-tumoral activity, as proven by means of GC-MS in the BC cell line MCF-7 cells [84].

Recently, chromatographic techniques coupled to MS helped to identify another oncometabolite downstream of 5,6-EPOX transformation by $\mathrm{ChEH}$, namely 6-oxo-cholestan-3 $\beta, 5 \alpha$-diol (OCDO), whose level in breast tissue of BC patients significantly increased, together with $\mathrm{ChEH}$ protein expression, in comparison to normal tissues [85].

B-ring oxysterols are suspected to interact with estrogen receptors and anti-estrogen binding sites (AEBS) and by this way to affect the efficacy of hormonal therapy [80]. Among the diverse oxysterols quantified by UPLC coupled with positive-ion APCI-MS/MS in plasma of BC patients before and after 12-24-months surgical removal of tumor, 7-KC significantly increased at the end 
point. This rise was found in all patients and also in a subgroup with estrogen receptor-expressing tumors treated with Tamoxifen, suggesting that 7-KC presence may be linked to tumor growth, independently of estrogenic activity [86].

Lastly, a novel filter and filter-back flush capillary LC system, followed by high-resolution MS, allowed to profile side chain-hydroxylated oxysterols even in exosomes, namely extra-cellular vesicles released by exocytosis, in particular by cancer cells. These particles, which may contain elevated levels of lipids, are typically present in very limited amounts. The results thus obtained showed that in a panel of either cancerous and not cancerous cells, the exosomal oxysterol content differed from the cytosolic one. In particular, 27-HC is more abundant in exosomes obtained from the estrogen receptor positive $\mathrm{BC}$ cells $\mathrm{MCF}-7$ versus estrogen receptor negative BC cells. Overall, the data point to exosomal oxysterols as more reliable markers for cancer diagnosis [87].

However, the actual correlation between oxysterol levels and $\mathrm{BC}$ incidence could be re-evaluated in the light of new observations. A very recent prospective study including 530 incident invasive BC cases, and employing LC-MS for oxysterol analysis, showed that serum 27-HC was not associated with $\mathrm{BC}$ risk overall. On the contrary, in postmenopausal women, higher 27-HC was even associated with a lower risk to develop BC [88]. Therefore, the use of oxysterols as markers of human BC should be carefully reconsidered.

In relation to this, a very recent quantification of side chain oxysterols performed by an advanced LC-MS technology on estrogen receptor positive and estrogen receptor negative BC specimens highlighted a large variation in their concentrations among the different specimens and even in the different sections from the same specimen. No significant difference was observed in oxysterol amount between estrogen receptor positive and estrogen receptor negative breast carcinomas. Such a great heterogeneity of oxysterol concentration in $\mathrm{BC}$ tissue questions the role of oxysterols in cancer growth [89].

\subsubsection{Liver and Bile Duct Cancer}

Even if the suitability of oxysterols as target analytes correlating with liver and bile duct carcinogenesis needs deeper investigation, some of these cholesterol oxides were proven to be associated with the chronic inflammatory states that may promote hepatic cancers. Indeed, an increase of $7 \alpha-\mathrm{HC}, 4 \beta-\mathrm{HC}$ and $25-\mathrm{HC}$ in serum of chronic hepatitis $\mathrm{C}$ patients was reported as assessed by LC-ESI-MS/MS. The evidence that $7 \alpha-\mathrm{HCO}$, a marker of cholesterol $7 \alpha$-hydroxylase 
activity, did not change in those patients would suggest that only oxysterols of non-enzymatic origin would be detectable in the inflammatory and pro-oxidant state that accompanies viral infections of the liver. Interestingly, the level of this compound decreased after 3 months of interferon anti-viral therapy, and it may therefore represent a marker for the evaluation of disease progression to hepatocarcinoma [90].

Similarly, by using GC-MS the B-ring oxysterols 7-ketocholesta-3,5-diene (7-KD), 3-ketocholest4-ene (3-K4), 3-ketocholest-7-ene (3-K7), 3-ketocholesta-4,6-diene (3-KD), and TRIOL were found in the liver of hamsters developing cholangiocarcinoma after infection with liver fluke. Among them, TRIOL and $3 \mathrm{~K} 4$ were also suspected to cause DNA damage in the setting of chronic inflammation [91].

\subsubsection{Colorectal Cancer}

As regards colorectal carcinogenesis hypercholesterolemia and obesity are likely among the major risk factors of cancer growth and progression [92]. Since a diet rich of animal fats is source of oxysterols, it is conceivable that these compounds would contribute to activate a sustained oxidative and inflammatory machinery in immune system cells leading to cancer development in the gut [93,94]. This hypothesis has been corroborated by the results provided by a HPLC-MS measurement of the level of 11 oxysterols in the colon and plasma of several models of murine colitis, as well as in colon biopsies from patients with the two main inflammatory bowel diseases, namely Crohn's disease and ulcerative colitis, well recognized precancerosis. $4 \beta-\mathrm{HC}$ and $25-\mathrm{HC}$ levels were found consistently altered in the colon of all animal models, whereas $7 \alpha-\mathrm{HCO}$ and $25-$ $\mathrm{HC}$ increased and 27-HC appeared to decrease in colon cancer patients [95].

\section{Conclusions}

The primary importance of cholesterol in human pathophysiology is nowadays unanimously established, and hypercholesterolemia is considered a risk factor in several chronic diseases and not only in atherosclerosis. Cholesterol oxidation generates a wide family of derivatives, termed oxysterols, that are provided with many biochemical and biological effects. The contribution of oxysterols to cholesterol pathophysiology has been investigated in a number of in vitro and in vivo 
models. The unanimous outcome of all these studies is that supra-physiological concentrations of oxysterols may exert pro-oxidant and pro-inflammatory effects.

Moreover, confirmation of the association between oxysterol levels and human chronic disease comes from a series of analyses aimed at characterizing oxysterol profile in various types of patients, and to evaluate its diagnostic and prognostic value. In this field, interest has been mainly dedicated to those pathologies that are definitely ascribed to defects in cholesterol metabolism (e.g. some neurodegenerative or hereditary disorders) or to hypercholesterolemia (e.g. cardiovascular disease, MetS), whereas, with regard to other pathologies, including cancer, oxysterol identification in biological specimens has been so far less considered.

In addition, data availability and consistency are limited because of technical aspects which make oxysterol detection in biological matrices quite difficult. Oxysterols are present at nanomolar amounts in tissues and biological fluids against the millimolar concentration of cholesterol. In addition, cholesterol is highly susceptible to oxidation, also during specimen processing, and this can easily lead to artifacts. Moreover, diverse oxysterols usually coexist in specimens: considering that these molecules have similar and thus analytical behavior, their precise identification in the same sample could be tough. In this regard, lipidomics techniques offer exceptional specificity and sensitivity, and therefore represent the best approach for qualitative and quantitative oxysterol determination.

Another important aspect to take into consideration is the necessity to recognize, for every pathology, the oxysterol pattern that specifically correlates with its onset and progression. This seems to be possible for some diseases for which definite oxysterols have been identified as possible hallmarks of occurrence. This is the case, for example, of DHCEO and 24-, 25-, 26-OH-8DHC in SLO assessment, or OCDO in BC evaluation. On the contrary, for many disorders, no oxysterols have been recognized so far as selective biomarkers. In fact, the modulation of the most frequently formed oxysterols (e.g. 7-KC, 7-OH, 24S-HC), reported in several investigations, is more likely an indication of generic inflammation and redox imbalance, or of incorrect diet, and is thus less informative for precise clinical applications. For the latter purpose, lipidomics can give again a helpful contribution, thus it is conceivable that future research effort will be addressed to improve disease-targeted identification and quantification of novel oxysterols by means of this methodology.

\section{Acknowledgments}


The work was supported by the Compagnia di San Paolo (CSTO167048) and the University of Torino (RILO2016 and RILO2017).

\section{Conflict of interest}

Authors declare not to have conflicts of interest.

\section{References}

[1] B. Barriuso, D. Ansorena, I. Astiasarán, Oxysterols formation: A review of a multifactorial process, J. Steroid Biochem. Mol. Biol. $169 \quad$ (2017) 39-45. https://doi.org/10.1016/j.jsbmb.2016.02.027.

[2] B. Sottero, G. Leonarduzzi, G. Testa, S. Gargiulo, G. Poli, F. Biasi, Lipid oxidation derived aldehydes and oxysterols between health and disease, Eur. J. Lipid Sci. Technol. 1700047 (2018) 1-16. https://doi.org/10.1002/ejlt.201700047.

[3] A.J. Brown, W. Jessup, Oxysterols and atherosclerosis, Atherosclerosis 142 (1999) 1-28.

[4] W. Luu, L.J. Sharpe, I. Capell-Hattam, I.C. Gelissen, A.J. Brown, Oxysterols: old tale, new twists, Annu. Rev. Pharmacol. Toxicol. 56 (2016) 447-467. https://doi.org/10.1146/annurevpharmtox-010715-103233

[5] S. Theofilopoulos, Y. Wang, S.S. Kitambi, P. Sacchetti, K.M. Sousa, K. Bodin, J. Kirk, C. Saltó, M. Gustafsson, E.M. Toledo, K. Karu, J. Å. Gustafsson, K.R. Steffensen, P. Ernfors, J. Sjövall, J.W. Griffiths, E. Arenas, Brain endogenous liver X receptor ligands selectively promote midbrain neurogenesis, Nat. Chem. Biol. 9 (2013) 126-133. https://doi.org/10.1038/nchembio.1156.

[6] D. Lembo, V. Cagno, A. Civra, G. Poli, Oxysterols: An emerging class of broad spectrum antiviral effectors, Mol. Aspects Med. 49 (2016) 23-30. https://doi.org/10.1016/j.mam.2016.04.003.

[7] G. Poli, F. Biasi, G. Leonarduzzi, Oxysterols in the pathogenesis of major chronic diseases, Redox Biol. 1 (2013) 125-130. https://doi.org/10.1016/j.redox.2012.12.001.

[8] W.J. Griffiths, Y. Wang, Sterolomics: state of the art, developments, limitations and challenges, Biochim. Biophys. Acta Mol. Cell Biol. Lipids 1862 (2017) 771-773. https://doi.org/10.1016/j.bbalip.2017.03.001.

[9] S. Dzeletovic, O. Breuer, E. Lund, U. Diczfalusy, Determination of cholesterol oxidation products in human plasma by isotope dilution-mass spectrometry, Anal. Biochem. 225 (1995) 73-80.

[10] H.F. Schött, D. Lütjohann, Validation of an isotope dilution gas chromatography-mass spectrometry method for combined analysis of oxysterols and oxyphytosterols in serum samples, Steroids 99 (2015) 139-50. https://doi.org/10.1016/j.steroids.2015.02.006. 
[11] C. Helmschrodt, S. Becker, J. Thiery, U. Ceglarek, Preanalytical standardization for reactive oxygen species derived oxysterol analysis in human plasma by liquid chromatography-tandem mass spectrometry, Biochem. Biophys. Res. Commun. 446 (2014) 726-730. https://doi.org/10.1016/j.bbrc.2013.12.087.

[12] J.G. McDonald, D.D. Smith, A.R. Stiles, D.W. Russell, A comprehensive method for extraction and quantitative analysis of sterols and secosteroids from human plasma, J. Lipid. Res. 53 (2012) 1399-1409. https://doi.org/10.1194/jlr.D022285.

[13] H. Roberg-Larsen, M.F. Strand, A. Grimsmo, P.A. Olsen, J.L. Dembinski, F. Rise, E. Lundanes, T. Greibrokk, S. Krauss, S.R. Wilson, High sensitivity measurements of active oxysterols with automated filtration/filter backflush-solid phase extraction-liquid chromatographymass spectrometry, J. Chromatogr. A 1255 (2012) 291-297. https://doi.org/10.1016/j.chroma. 2012.02.002.

[14] P. Kylli, T. Hankemeier, R. Kostiainen, Feasibility of ultra-performance liquid chromatography-ion mobility-time-of-flight mass spectrometry in analyzing oxysterols, J. Chromatogr. A 1487 (2017) 147-152. https://doi.org/10.1016/j.chroma.2017.01.039.

[15] G. Testa, D. Rossin, G. Poli, F. Biasi, G. Leonarduzzi, Implication of oxysterols in chronic inflammatory human diseases, Biochimie 153 (2018) 220-231. https://doi.org/10.1016/ j.biochi.2018.06.006.

[16] S. Garcia-Cruset, K.L. Carpenter, F. Guardiola, M.J. Mitchinson, Oxysterols in cap and core of human advanced atherosclerotic lesions, Free Radic. Res. 30 (1999) 341-350.

[17] S. Garcia-Cruset, K.L. Carpenter, F. Guardiola, B.K. Stein, M.J. Mitchinson, Oxysterol profiles of normal human arteries, fatty streaks and advanced lesions, Free Radic. Res. 35 (2001) $31-41$.

[18] S. Gargiulo, P. Gamba, G. Testa, G. Leonarduzzi, G. Poli, The role of oxysterols in vascular ageing, J. Physiol. 594 (2016) 2095-2113. https://doi.org/10.1113/JP271168.

[19] C. Helmschrodt, S. Becker, J. Schröter, M. Hecht, G. Aust, J. Thiery, U. Ceglarek, Fast LCMS/MS analysis of free oxysterols derived from reactive oxygen species in human plasma and carotid plaque, Clin. Chim. Acta 425 (2013) 3-8. https://doi.org/10.1016/j.cca.2013.06.022.

[20] V.W. Virginio, V.S. Nunes, F.A. Moura, F.H. Menezes, N.A. Andreollo, F. Rogerio, D.Z. Scherrer, E.C. Quintão, E. Nakandakare, O. Petrucci, W. Nadruz-Junior, E.C. de Faria, A.C. Sposito, Arterial tissue and plasma concentration of enzymatic-driven oxysterols are associated with severe peripheral atherosclerotic disease and systemic inflammatory activity, Free Radic. Res. 49 (2015) 199-203. https://doi.org/10.3109/10715762.2014.992894.

[21] L. Baila-Rueda, A. Cenarro, I. Lamiquiz-Moneo, R. Mateo-Gallego, A.M. Bea, S. PerezCalahorra, V. Marco-Benedi, F. Civeira, Bile acid synthesis precursors in subjects with genetic hypercholesterolemia negative for LDLR/APOB/PCSK9/APOE mutations. Association with lipids and carotid atherosclerosis, J. Steroid. Biochem. Mol. Biol. 169 (2017) 226-233. https://doi.org/10.1016/j.jsbmb.2016.10.003. 
[22] G.S. Ferreira, P.R. Pinto, R.T. Iborra, V. Del Bianco, M.F.M. Santana, E.R. Nakandakare, V.S. Nunes, C.E. Negrão, S. Catanozi, M. Passarelli, Aerobic Exercise Training Selectively Changes Oxysterol Levels and Metabolism Reducing Cholesterol Accumulation in the Aorta of Dyslipidemic Mice, Front. Physiol. 8 (2017) 644. https://doi.org/10.3389/fphys.2017.00644.

[23] J. Poirier, K.A. Cockell, W.M. Ratnayake, K.A. Scoggan, N. Hidiroglou, C. Gagnon, H. Rocheleau, H. Gruber, P. Griffin, R. Madère, K. Trick, S. Kubow, Antioxidant Supplements Improve Profiles of Hepatic Oxysterols and Plasma Lipids in Butter-fed Hamsters, Nutr. Metab. Insights 3 (2010) 1-14. https://doi.org/:10.4137/NMI.S3911.

[24] J.H. Dumolt, S.K. Radhakrishnan, M.H. Moghadasian, K. Le, M.S. Patel, R.W. Browne, T.C. Rideout, Maternal hypercholesterolemia enhances oxysterol concentration in mothers and newly weaned offspring but is attenuated by maternal phytosterol supplementation, J. Nutr. Biochem. 52 (2018) 10-17. https://doi.org/10.1016/j.jnutbio.2017.09.013.

[25] I.H.K. Dias, I. Milic, G.Y.H. Lip, A. Devitt, M.C. Polidori, H.R. Griffiths, Simvastatin reduces circulating oxysterol levels in men with hypercholesterolaemia, Redox Biol. 16 (2018) 139-145. https://doi.org/10.1016/j.redox.2018.02.014.

[26] L.J. Sharpe, V. Burns, A.J. Brown, A lipidomic perspective on intermediates in cholesterol synthesis as indicators of disease status, J. Genet. Genomics 41 (2014) 275-282. https://doi.org/10.1016/j.jgg.2014.03.001.

[27] A.E. DeBarber, J. Luo, R. Giugliani, C.F. Souza, J.P. Chiang, L.S. Merkens, A.S. Pappu, R.D. Steiner, A useful multi-analyte blood test for cerebrotendinous xanthomatosis, Clin. Biochem. 47 (2014) 860-863. https://doi.org/10.1016/j.clinbiochem.2014.04.017.

[28] P.J. Crick, T. William Bentley, J. Abdel-Khalik, I. Matthews, P.T. Clayton, A.A. Morris, B.W. Bigger, C. Zerbinati, L. Tritapepe, L. Iuliano, Y. Wang, W.J. Griffiths, Quantitative charge-tags for sterol and oxysterol analysis, Clin. Chem. 61 (2015) 400-411. https://doiorg/10.1373/clinchem.2014.231332.

[29] W.J. Griffiths, P.J. Crick, A. Meljon, S. Theofilopoulos, J. Abdel-Khalik, E. Yutuc, J.E. Parker, D.E. Kelly, S.L. Kelly, E. Arenas, Y. Wang, Additional pathways of sterol metabolism: Evidence from analysis of Cyp27a1-/- mouse brain and plasma, Biochim. Biophys. Acta Mol. Cell. Biol. Lipids 1864 (2019) 191-211. https://doi.org/10.1016/j.bbalip.2018.11.006.

[30] R. Hutcheson, P. Rocic, The metabolic syndrome, oxidative stress, environment, and cardiovascular disease: the great exploration, Exp. Diabetes Res. 2012 (2012) 271028. https://doi.org/10.1155/2012/271028.

[31] G. Murdolo, M. Piroddi, C. Tortoioli, D. Bartolini, M. Schmelz, F. Luchetti, B. Canonico, S. Papa, C. Zerbinati, L. Iuliano, F. Galli, Free Radical-derived Oxysterols: Novel Adipokines Modulating Adipogenic Differentiation of Adipose Precursor Cells, J. Clin. Endocrinol. Metab. 101 (2016) 4974-4983. https://doi.org/10.1210/jc.2016-2918.

[32] J.S. Wooten, H. Wu, J. Raya, X.D. Perrard, J. Gaubatz, R.C. Hoogeveen, The Influence of an Obesogenic Diet on Oxysterol Metabolism in C57BL/6J Mice. Cholesterol 2014 (2014) 843468. https://doi.org/10.1155/2014/843468. 
[33] V. Mutemberezi, J. Masquelier, O. Guillemot-Legris, G.G. Muccioli, Development and validation of an HPLC-MS method for the simultaneous quantification of key oxysterols, endocannabinoids, and ceramides: variations in metabolic syndrome, Anal. Bioanal. Chem. 408 (2016) 733-745. https://doi.org/10.1007/s00216-015-9150-z.

[34] O. Guillemot-Legris, V. Mutemberezi, G.G. Muccioli, Oxysterols in Metabolic Syndrome: From Bystander Molecules to Bioactive Lipids, Trends Mol. Med. 22 (2016) 594-614. https://doi.org/10.1016/j.molmed.2016.05.006.

[35] M. Tremblay-Franco, C. Zerbinati, A. Pacelli, G. Palmaccio, C. Lubrano, S. Ducheix, H. Guillou, L. Iuliano, Effect of obesity and metabolic syndrome on plasma oxysterols and fatty acids in human, Steroids 99 (2015) 287-292. https://doi.org/10.1016/j.steroids.2015.03.019.

[36] D.L. Lu, D. Sookthai, C. Le Cornet, V.A. Katzke, T.S. Johnson, R. Kaaks, R.T. Fortner, Reproducibility of serum oxysterols and lanosterol among postmenopausal women: Results from $\begin{array}{llrrr}\text { EPIC-Heidelberg, } & \text { Clin. } & \text { Biochem. } & 52 & \text { (2018) }\end{array}$ https://doi.org/10.1016/j.clinbiochem.2017.11.001.

[37] D. Alkazemi, G. Egeland, J. Vaya, S. Meltzer, S. Kubow, Oxysterol as a marker of atherogenic dyslipidemia in adolescence, J. Clin. Endocrinol. Metab. 93 (2008) 4282-4289. https://doi.org/10.1210/jc.2008-0586.

[38] A. Szuchman, M. Aviram, R. Musa, S. Khatib, J. Vaya, Characterization of oxidative stress in blood from diabetic vs. hypercholesterolaemic patients, using a novel synthesized marker, Biomarkers 13 (2008) 119-131. https://doi.org/10.1080/13547500701614556.

[39] A. Samadi, A. Gurlek, S.N. Sendur, S. Karahan, F. Akbiyik, I. Lay, Oxysterol species: reliable markers of oxidative stress in diabetes mellitus, J. Endocrinol. Invest. 42 (2019) 7-17. https://doi.org/10.1007/s40618-018-0873-5.

[40] T. Ikegami, H. Hyogo, A. Honda, T. Miyazaki, K. Tokushige, E. Hashimoto, K. Inui, Y. Matsuzaki, S. Tazuma, Increased serum liver X receptor ligand oxysterols in patients with nonalcoholic fatty liver disease, J. Gastroenterol. 47 (2012) 1257-1266. https://doi.org/10.1007/s00535012-0585-0.

[41] I. Björkhem, A. Cedazo-Minguez, V. Leoni, S. Meaney, Oxysterols and neurodegenerative diseases, Mol. Aspects Med. 30 (2009) 171-179. https://doi.org/10.1016/j.mam.2009.02.001.

[42] Z. Liu, T. Zhou, A.C. Ziegler, P. Dimitrion, L. Zuo, Oxidative Stress in Neurodegenerative Diseases: From Molecular Mechanisms to Clinical Applications, Oxid. Med. Cell. Longev. 2017 (2017) 2525967. https://doi.org/10.1155/2017/2525967.

[43] L. Iuliano, P.J. Crick, C. Zerbinati, L. Tritapepe, J. Abdel-Khalik, M. Poirot, Y. Wang, W.J. Griffiths, Cholesterol metabolites exported from human brain, Steroids 99 (2015) 189-193. https://doi.org/10.1016/j.steroids.2015.01.026.

[44] I. Björkhem, V. Leoni, P. Svenningsson, On the fluxes of side-chain oxidized oxysterols across blood-brain and blood-CSF barriers and origin of these steroids in CSF (Review), J. Steroid. $\begin{array}{llllll}\text { Biochem. } & \text { Mol. } & \text { Biol. } & \text { pii: } & \text { S0960-0760 30733-30737. }\end{array}$ https://doi.org/10.1016/j.jsbmb.2018.12.009. [Epub ahead of print] 
[45] V. Leoni, C. Caccia, Oxysterols as biomarkers in neurodegenerative diseases, Chem. Phys. Lipids 164 (2011) 515-524. https://doi.org/10.1016/j.chemphyslip.2011.04.002.

[46] V. Leoni, C. Caccia, Potential diagnostic applications of side chain oxysterols analysis in plasma and cerebrospinal fluid, Biochem. Pharmacol. 86 (2013) 26-36. https://doi.org/10.1016/j.bcp.2013.03.015.

[47] T. Nury, A. Zarrouk, A. Vejux, M. Doria, J.M. Riedinger, R. Delage-Mourroux, G. Lizard, Induction of oxiapoptophagy, a mixed mode of cell death associated with oxidative stress, apoptosis and autophagy, on 7-ketocholesterol-treated $158 \mathrm{~N}$ murine oligodendrocytes: impairment by $\alpha-$ tocopherol, Biochem. Biophys. Res. Commun. $446 \quad$ (2014) 714-719. https://doi.org/10.1016/j.bbrc.2013.11.081

[48] M. Reinicke, J. Schröter, D. Müller-Klieser, C. Helmschrodt, Ceglarek U. Free oxysterols and bile acids including conjugates - Simultaneous quantification in human plasma and cerebrospinal fluid by liquid chromatography-tandem mass spectrometry, Anal. Chim. Acta 1037 (2018) 245255. https://doi.org/10.1016/j.aca.2018.02.049.

[49] V. Mutemberezi, B. Buisseret, J. Masquelier, O. Guillemot-Legris, M. Alhouayek, G.G. Muccioli, Oxysterol levels and metabolism in the course of neuroinflammation: insights from in vitro and in vivo models, J. Neuroinflammation 15 (2018) 74. https://doi.org/10.1186/s12974-0181114-8.

[50] P. Gamba, G. Testa, S. Gargiulo, E. Staurenghi, G. Poli, G. Leonarduzzi, Oxidized cholesterol as the driving force behind the development of Alzheimer's disease, Front. Aging Neurosci. 7 (2015) 119. https://doi.org/10.3389/fnagi.2015.00119.

[51] A. Besga, A. Cedazo-Minguez, I. Kåreholt, A. Solomon, I. Björkhem, B. Winblad, V. Leoni, B. Hooshmand, G. Spulber, A. Gonzalez-Pinto, M. Kivipelto, L.O. Wahlund, Differences in brain cholesterol metabolism and insulin in two subgroups of patients with different CSF biomarkers but similar white matter lesions suggest different pathogenic mechanisms, Neurosci. Lett. 510 (2012) 121-126. https://doi.org/10.1016/j.neulet.2012.01.017.

[52] G. Testa, E. Staurenghi, C. Zerbinati, S. Gargiulo, L. Iuliano, G. Giaccone, F. Fantò, G. Poli, G. Leonarduzzi, P. Gamba, Changes in brain oxysterols at different stages of Alzheimer's disease: Their involvement in neuroinflammation, Redox Biol. $10 \quad$ (2016) 24-33. https://doi.org/10.1016/j.redox.2016.09.001.

[53] Q. Liu, Y. An, H. Yu, Y. Lu, L. Feng, C. Wang, R. Xiao, Relationship between oxysterols and mild cognitive impairment in the elderly: a case-control study, Lipids Health Dis. 15 (2016) 177. https://doi.org/10.1186/s12944-016-0344-y.

[54] H.H. Son, D.Y. Lee, H.S. Seo, J. Jeong, J.Y. Moon, J.E. Lee, B.C. Chung, E. Kim, M.H. Choi,

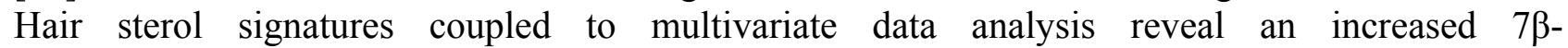
hydroxycholesterol production in cognitive impairment, J. Steroid. Biochem. Mol. Biol. 55 (2016) 9-17. https://doi.org/10.1016/j.jsbmb.2015.09.024.

[55] R. Paul, A. Choudhury, A. Borah, Cholesterol - A putative endogenous contributor towards Parkinson's disease, Neurochem. Int. $90 \quad$ (2015) 125-133. https://doi.org/10.1016/j.neuint.2015.07.025. 
[56] I. Björkhem, A. Lövgren-Sandblom, V. Leoni, S. Meaney, L. Brodin, L. Salveson, K. Winge, S. Pålhagen, P. Svenningsson, Oxysterols and Parkinson's disease: evidence that levels of 24Shydroxycholesterol in cerebrospinal fluid correlates with the duration of the disease, Neurosci. Lett. 555 (2013) 102-105. https://doi.org/10.1016/j.neulet.2013.09.003.

[57] I. Björkhem, V. Leoni, P. Svenningsson, On the fluxes of side-chain oxidized oxysterols across blood-brain and blood-CSF barriers and origin of these steroids in CSF (Review), J. Steroid Biochem. Mol. Biol. (2018) pii: S0960-0760(18)30733-7. https://doi.org/10.1016/j.jsbmb.2018.12.009.

[58] D. Cheng, A.M. Jenner, G. Shui, W.F. Cheong, T.W. Mitchell, J.R. Nealon, W.S. Kim, H. McCann, M.R. Wenk, G.M. Halliday, B. Garner, Lipid pathway alterations in Parkinson's disease primary visual cortex, PLoS One 6 (2011) e17299. https://doi.org/10.1371/journal.pone.0017299.

[59] M. Piraud, M. Pettazzoni, P. Lavoie, S. Ruet, C. Pagan, D. Cheillan, P. Latour, C. VianeySaban, C. Auray-Blais, R. Froissart, Contribution of tandem mass spectrometry to the diagnosis of lysosomal storage disorders, J. Inherit Metab. Dis. 41 (2018) 457-477. https://doi.org/10.1007/s10545-017-0126-3.

[60] F. Kannenberg, J.R. Nofer, E. Schulte, J. Reunert, T. Marquardt, M. Fobker, Determination of serum cholestane-3 $\beta, 5 \alpha, 6 \beta$-triol by gas chromatography-mass spectrometry for identification of Niemann-Pick type C (NPC) disease, J. Steroid Biochem. Mol. Biol. 169 (2017) 54-60. https://doi.org/10.1016/j.jsbmb.2016.02.030.

[61] G. Polo, A. Burlina, F. Furlan, T. Kolamunnage, M. Cananzi, L. Giordano, M. Zaninotto, M. Plebani, A. Burlina, High level of oxysterols in neonatal cholestasis: a pitfall in analysis of biochemical markers for Niemann-Pick type C disease, Clin. Chem. Lab. Med. 54 (2016) 12211229. https://doi.org/10.1515/cclm-2015-0669.

[62] M. Romanello, S. Zampieri, N. Bortolotti, L. Deroma, A. Sechi, A. Fiumara, R. Parini, B. Borroni, F. Brancati, A. Bruni, C.V. Russo, A. Bordugo, B. Bembi, A. Dardis, Comprehensive Evaluation of Plasma 7-Ketocholesterol and Cholestan-3 $\beta, 5 \alpha, 6 \beta$-Triol in an Italian Cohort of Patients Affected by Niemann-Pick Disease due to NPC1 and SMPD1 Mutations, Clin. Chim. Acta 455 (2016) 39-45. https://doi.org/10.1016/j.cca.2016.01.003.

[63] W.J. Griffiths, I. Gilmore, E. Yutuc, J. Abdel-Khalik, P.J. Crick, T. Hearn, A. Dickson, B.W. Bigger, T.H. Wu, A. Goenka, A. Ghosh, S.A. Jones, Y. Wang, Identification of unusual oxysterols and bile acids with 7 -oxo or $3 \beta, 5 \alpha, 6 \beta$-trihydroxy functions in human plasma by charge-tagging mass spectrometry with multistage fragmentation, J. Lipid Res. 59 (2018) 1058-1070. https://doi.org/10.1194/jlr.D083246.

[64] S. Mukhopadhyay, K. Fellows, R.W. Browne, P. Khare, S. Krishnan Radhakrishnan, J. Hagemeier, B. Weinstock-Guttman, R. Zivadinov, M. Ramanathan, Interdependence of oxysterols with cholesterol profiles in multiple sclerosis, Mult. Scler. 23 (2017) 792-801. https://doi.org/10.1177/1352458516666187.

[65] R. Narayanaswamy, V. Iyer, P. Khare, M.L. Bodziak, D. Badgett, R. Zivadinov, B. WeinstockGuttman, T.C. Rideout, M. Ramanathan, R.W. Browne, Simultaneous determination of oxysterols, cholesterol and 25-hydroxy-vitamin D3 in human plasma by LC-UV-MS, PLoS One 10 (2015) e0123771. https://doi.org/10.1371/journal.pone.0123771. 
[66] A. Vejux, A. Namsi, T. Nury, T. Moreau, G. Lizard, Biomarkers of Amyotrophic Lateral Sclerosis: Current Status and Interest of Oxysterols and Phytosterols, Front. Mol. Neurosci. 11 (2018) 12. https://doi.org/10.3389/fnmol.2018.00012.

[67] S.M. Kim, M.Y. Noh, H. Kim, S.Y. Cheon, K.M. Lee, J. Lee, E. Cha, K.S. Park, K.W. Lee, J.J. Sung, S.H. Kim, 25-Hydroxycholesterol is involved in the pathogenesis of amyotrophic lateral sclerosis, Oncotarget 8 (2017) 11855-11867. https://doi.org/10.18632/oncotarget.14416.

[68] A. Wuolikainen, J. Acimovic, A. Lövgren-Sandblom, P. Parini, P.M Andersen, I. Björkhem, Cholesterol, oxysterol, triglyceride, and coenzyme Q homeostasis in ALS. Evidence against the hypothesis that elevated 27-hydroxycholesterol is a pathogenic factor, PLoS One 9 (2014) e113619. https://doi.org/10.1371/journal.pone.0113619.

[69] J. Abdel-Khalik, E. Yutuc, P.J. Crick, J.Å. Gustafsson, M. Warner, G. Roman, K. Talbot, E. Gray, W.J. Griffiths, M.R. Turner, Y. Wang, Defective cholesterol metabolism in amyotrophic lateral sclerosis, J. Lipid Res. 58 (2017) 267-278. https://doi.org/10.1194/jlr.P071639.

[70] F. Kreilaus, A.S. Spiro, C.A. McLean, B. Garner, A.M. Jenner, Evidence for altered cholesterol metabolism in Huntington's disease post mortem brain tissue, Neuropathol. Appl. Neurobiol. 42 (2016) 535-546. https://doi.org/10.1111/nan.12286.

[71] I. Björkhem, U. Diczfalusy, A. Lövgren-Sandblom, L. Starck, M. Jonsson, K. Tallman, H. Schirmer, L.B. Ousager, P.J. Crick, Y. Wang, W.J. Griffiths, F.P. Guengerich, On the formation of 7-ketocholesterol from 7-dehydrocholesterol in patients with CTX and SLO, J. Lipid Res. 55 (2014) 1165-1172. https://doi.org/10.1194/jlr.P048603.

[72] W.J. Griffiths, J. Abdel-Khalik, P.J. Crick, M. Ogundare, C.H. Shackleton, K. Tuschl, M.K. Kwok, B.W. Bigger, A.A. Morris, A. Honda, L. Xu, N.A. Porter, I. Björkhem, P.T. Clayton, Y. Wang, Sterols and oxysterols in plasma from Smith-Lemli-Opitz syndrome patients, J. Steroid. Biochem. Mol. Biol. 169 (2017) 77-87. https://doi.org/10.1016/j.jsbmb.2016.03.018.

[73] Z. Korade, L. Xu, K. Mirnics, N.A. Porter, Lipid biomarkers of oxidative stress in a genetic mouse model of Smith-Lemli-Opitz syndrome, J. Inherit. Metab. Dis. 36 (2013) 113-122. https://doi.org/10.1007/s10545-012-9504-z.

[74] A. Meljon, G.L. Watson, Y. Wang, C.H. Shackleton, W.J. Griffiths, Analysis by liquid chromatography-mass spectrometry of sterols and oxysterols in brain of the newborn Dhcr7( $\Delta 3$ 5/T93M) mouse: a model of Smith-Lemli-Opitz syndrome, Biochem. Pharmacol. 86 (2013) 43-55. https://doi.org/10.1016/j.bcp.2013.03.003.

[75] L. Xu, W. Liu, L.G. Sheflin, S.J. Fliesler, N.A. Porter, Novel oxysterols observed in tissues and fluids of AY9944-treated rats: a model for Smith-Lemli-Opitz syndrome, J. Lipid Res. 52 (2011) 1810-1820. https://doi.org/10.1194/jlr.M018366.

[76] R. Filomenko, C. Fourgeux, L. Bretillon, S. Gambert-Nicot, Oxysterols: Influence on plasma membrane rafts microdomains and development of ocular diseases, Steroids 99 (2015) 259-265. https://doi.org/10.1016/j.steroids.2015.02.004.

[77] I.R. Rodriguez, S.J. Fliesler, Photodamage generates 7-keto- and 7-hydroxycholesterol in the rat retina via a free radical-mediated mechanism, Photochem. Photobiol. 85 (2009) 1116-1125. https://doi.org/10.1111/j.1751-1097.2009.00568.x. 
[78] B. Dasari, J.R. Prasanthi, G. Marwarha, B.B. Singh, O. Ghribi, Cholesterol-enriched diet causes age-related macular degeneration-like pathology in rabbit retina, BMC Ophthalmol. 11 (2011) 2. https://doi.org/10.1186/1471-2415-11-22.

[79] J.B. Lin, A. Sene, A. Santeford, H. Fujiwara, R. Sidhu, M.M. Ligon, V.A. Shankar, N. Ban, I.U. Mysorekar, D.S. Ory, R.S. Apte, Oxysterol Signatures Distinguish Age-Related Macular Degeneration from Physiologic Aging, EBioMedicine 32 (2018) 9-20. https://doi.org/10.1016/j.ebiom.2018.05.035.

[80] A. Kloudova, F.P. Guengerich, P. Soucek, The Role of Oxysterols in Human Cancer, Trends Endocrinol. Metab. 28 (2017) 485-496. https://doi.org/10.1016/j.tem.2017.03.002.

[81] S. Silvente-Poirot, F. Dalenc, M. Poirot, The Effects of Cholesterol-Derived Oncometabolites on Nuclear Receptor Function in Cancer, Cancer Res. 78 (2018) 4803-4808. https://doi.org/10.1158/0008-5472.CAN-18-1487.

[82] G. Poli, F. Biasi, Potential modulation of cancer progression by oxysterols, Mol. Aspects Med. 49 (2016) 47-48. https://doi.org/10.1016/j.mam.2016.04.002.

[83] F. Dalenc, L. Iuliano, T. Filleron, C. Zerbinati, M. Voisin, C. Arellano, E. Chatelut, P. Marquet, M. Samadi, H. Roché, M. Poirot, S. Silvente-Poirot, Circulating oxysterol metabolites as potential new surrogate markers in patients with hormone receptor-positive breast cancer: Results of the OXYTAM study, J. Steroid Biochem. Mol. Biol. 169 (2017) 210-218. https://doi.org/10.1016/j.jsbmb.2016.06.010.

[84] G. Segala, P. de Medina, L. Iuliano, C. Zerbinati, M.R. Paillasse, E. Noguer, F. Dalenc, B. Payré, V.C. Jordan, M. Record, S. Silvente-Poirot, M. Poirot, 5,6-Epoxy-cholesterols contribute to the anticancer pharmacology of tamoxifen in breast cancer cells, Biochem. Pharmacol. 86 (2013) 175-189. https://doi.org/10.1016/j.bcp.2013.02.031.

[85] M. Voisin, P. de Medina, A. Mallinger, F. Dalenc, E. Huc-Claustre, J. Leignadier, N. Serhan, R. Soules, G. Ségala, A. Mougel, E. Noguer, L. Mhamdi, E. Bacquié, L. Iuliano, C. Zerbinati, M. Lacroix-Triki, L. Chaltiel, T. Filleron, V. Cavaillès, T. Al Saati, P. Rochaix, R. Duprez-Paumier, C. Franchet, L. Ligat, F. Lopez, M. Record, M. Poirot, S. Silvente-Poirot, Identification of a tumorpromoter cholesterol metabolite in human breast cancers acting through the glucocorticoid receptor, Proc. Natl. Acad. Sci. U S A 114 (2017) E9346-E9355. https://doi.org/10.1073/pnas.1707965114.

[86] P. Soucek, D. Vrana, Y.F. Ueng, S. Wei, R. Kozevnikovova, F.P. Guengerich, Selective changes in cholesterol metabolite levels in plasma of breast cancer patients after tumor removal, Clin. Chem. Lab. Med. 56 (2018) e78-e81. https://doi.org/10.1515/cclm-2017-0409.

[87] H. Roberg-Larsen, K. Lund, K.E. Seterdal, S. Solheim, T. Vehus, N. Solberg, S. Krauss, E. Lundanes, S.R. Wilson, Mass spectrometric detection of 27-hydroxycholesterol in breast cancer exosomes, J. Steroid Biochem. Mol. Biol. $169 \quad$ (2017) 22-28. https://doi.org/10.1016/j.jsbmb.2016.02.006.

[88] D.L. Lu, C. Le Cornet, D. Sookthai, T.S. Johnson, R. Kaaks, R.T. Fortner, Circulating 27Hydroxycholesterol and Breast Cancer Risk: Results From the EPIC-Heidelberg Cohort, J. Natl. Cancer Inst. (2018). https://doi.org/10.1093/jnci/djy115. [Epub ahead of print] 
[89] S. Solheim, S.A. Hutchinson, E. Lundanes, S.R. Wilson, J.L. Thorne, H. Roberg-Larsen, Fast liquid chromatography-mass spectrometry reveals side chain oxysterol heterogeneity in breast cancer tumour samples, J. Steroid Biochem. Mol. Biol. (2019) pii: S0960-0760(18)30754-4. https://doi.org/10.1016/j.jsbmb.2019.02.004. [Epub ahead of print]

[90] T. Ikegami, A. Honda, T. Miyazaki, M. Kohjima, M. Nakamuta, Y. Matsuzaki, Increased serum oxysterol concentrations in patients with chronic hepatitis $\mathrm{C}$ virus infection, Biochem. Biophys. Res. Commun. 446 (2014) 736-740. https://doi.org/10.1016/j.bbrc.2014.01.176

[91] A. Jusakul, W. Loilome, N. Namwat, W.G. Haigh, R. Kuver, S. Dechakhamphu, P. Sukontawarin, S. Pinlaor, S.P. Lee, P. Yongvanit, Liver fluke-induced hepatic oxysterols stimulate DNA damage and apoptosis in cultured human cholangiocytes, Mutat. Res. 731 (2012) 48-57. https://doi.org/10.1016/j.mrfmmm.2011.10.009.

[92] P.J. Tárraga López, J.S. Albero, J.A. Rodríguez-Montes, Primary and secondary prevention of colorectal cancer, Clin. Med. Insights Gastroenterol. $7 \quad$ (2014) 33-46. https://doi.org/10.4137/CGast.S14039.

[93] D. Rossin, S. Calfapietra, B. Sottero, G. Poli, F. Biasi, HNE and cholesterol oxidation products in colorectal inflammation and carcinogenesis, Free Radic. Biol. Med. 111 (2017) 186-195. https://doi.org/10.1016/j.freeradbiomed.2017.01.017.

[94] T. Willinger, Oxysterols in intestinal immunity and inflammation, J. Intern. Med. (2018). https://doi.org/10.1111/joim.12855. [Epub ahead of print]

[95] O. Guillemot-Legris, V. Mutemberezi, B. Buisseret, A. Paquot, V. Palmieri, P. Bottemanne, J. Lemaire, J.F. Rahier, M. Alhouayek, G.G. Muccioli, Colitis alters oxysterol metabolism and is

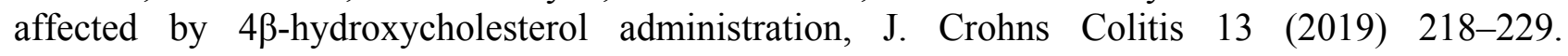
https://doi.org/10.1093/ecco-jcc/jjy157. 
Table 1.

Oxysterol evaluation in pathological conditions by lipidomics analyses of human specimens. (total: an alkaline hydrolysis step was performed to give free and esterified oxysterols)

\begin{tabular}{|c|c|c|c|c|c|c|}
\hline PATHOLOGY & $\begin{array}{l}\text { ANALYTICAL } \\
\text { ASPECTS }\end{array}$ & SUBJECTS & SPECIMEN & ANALYTES & MAIN OBSERVATIONS & REF. \\
\hline \multirow{2}{*}{ 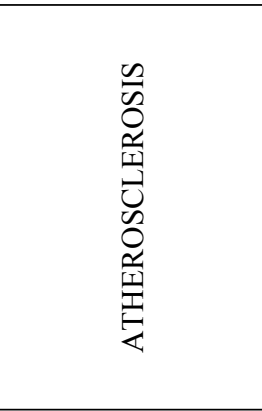 } & $\begin{array}{l}\text { one-step protein } \\
\text { precipitation and } \\
\text { concentration followed by } \\
\text { LC-APCI }(+)-\mathrm{MS} / \mathrm{MS}\end{array}$ & $\begin{array}{l}\text { healthy middle-aged } \\
\text { volunteers and } \\
\text { patients undergoing } \\
\text { carotid } \\
\text { endoarterectomy }\end{array}$ & $\begin{array}{l}\text { plasma and } \\
\text { carotid plaques }\end{array}$ & $\begin{array}{l}\text { (free) } \\
7-\mathrm{KC}, 7 \alpha / 7 \beta-\mathrm{HC}, 5 \alpha, 6 \alpha-\mathrm{EPOX} \text {, } \\
5 \beta, 6 \beta \text {-EPOX, TRIOL }\end{array}$ & $\begin{array}{l}\text { the chromatographic conditions } \\
\text { do not allow separation between } \\
7 \alpha-\text { and } 7 \beta-\mathrm{HC} \\
\text { oxysterol accumulation in } \\
\text { carotid plaques }\end{array}$ & [19] \\
\hline & $\begin{array}{l}\text { isotope dilution } \\
\text { GC-MS }\end{array}$ & $\begin{array}{l}\text { patients with severe } \\
\text { peripheral artery } \\
\text { disease }\end{array}$ & $\begin{array}{l}\text { plasma } \\
\text { arteries }\end{array}$ & $\begin{array}{l}\text { (total) } \\
24 \mathrm{~S}-\mathrm{HC}, 25-\mathrm{HC}, 27-\mathrm{HC}\end{array}$ & $\begin{array}{l}\text { plasma: } 25-\mathrm{HC} \uparrow \\
\text { arteries: } 24 \mathrm{~S}-\mathrm{HC} \uparrow 27-\mathrm{HC} \uparrow \\
\text { (vs. controls) }\end{array}$ & {$[20]$} \\
\hline \multirow{2}{*}{ 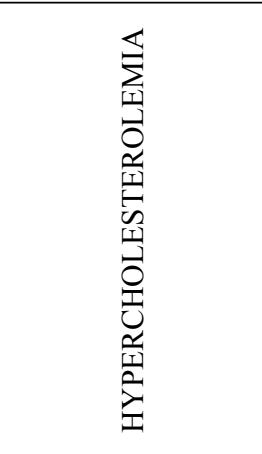 } & $\begin{array}{l}\text { semi-quantitative } \\
\text { HPLC-MS/MS }\end{array}$ & $\begin{array}{l}\text { patients with primary } \\
\text { hypercholesterolemia } \\
\text { of genetic origin }\end{array}$ & serum & $\begin{array}{l}\text { (total) } \\
7 \alpha-\mathrm{HCO}, 24 \mathrm{~S}-\mathrm{HC}, 27-\mathrm{HC}\end{array}$ & $\begin{array}{l}\text { all oxysterols } \uparrow \\
\text { (vs. controls) }\end{array}$ & {$[21]$} \\
\hline & $\begin{array}{l}\text { isotope dilution } \\
\text { LC-MS/MS } \\
\text { operating in MRM }\end{array}$ & $\begin{array}{l}\text { asymptomatic } \\
\text { hypercholesterolemic } \\
\text { patients in treatment } \\
\text { with Simvastatin }\end{array}$ & $\begin{array}{l}\text { plasma } \\
\text { (0 and 3-month } \\
\text { follow-up) }\end{array}$ & $\begin{array}{l}\text { (free) } \\
7-\mathrm{KC}, 7 \beta-\mathrm{HC}, 24 \mathrm{~S}-\mathrm{HC}, 25-\mathrm{HC} \text {, } \\
27-\mathrm{HC}\end{array}$ & $\begin{array}{l}\text { baseline: } 7 \beta-\mathrm{HC} \uparrow 25-\mathrm{HC} \uparrow \\
7-\mathrm{KC} \uparrow \\
\text { (vs. controls, normalized to total } \\
\text { cholesterol) } \\
\text { 3-month follow up: same control } \\
\text { level (normalized to total } \\
\text { cholesterol) }\end{array}$ & {$[25]$} \\
\hline \multirow{2}{*}{ 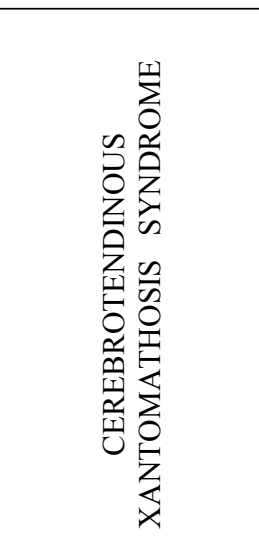 } & $\begin{array}{l}\text { keto derivatization } \\
\text { followed by } \\
\text { isotope dilution } \\
\text { LC-ESI-MS/MS }\end{array}$ & $\begin{array}{l}\text { CTX untreated } \\
\text { patients }\end{array}$ & plasma & $\begin{array}{l}\text { (free) } \\
7 \alpha-\mathrm{HCO}, 7 \alpha, 12 \alpha-d i H C O, \\
7 \alpha, 12 \alpha \text {-dihydroxy-4-cholestan-3-one }\end{array}$ & $\begin{array}{l}\text { all oxysterols } \uparrow \\
\text { (vs. controls) }\end{array}$ & [27] \\
\hline & $\begin{array}{l}\text { charge-tagging with } \\
\text { isotope-labeled Girard P } \\
\text { reagent derivatization } \\
\text { followed by LC-MS }\end{array}$ & CTX patients & plasma & $\begin{array}{l}\text { (free) } \\
\text { over } 20 \text { oxysterols including } 7 \alpha-H C \text {, } \\
27-H C, 7 \alpha, 12 \alpha \text {-diHC, sterols with } \\
\text { 3-oxo or 3-hydroxy group }\end{array}$ & $\begin{array}{l}7 \alpha-\mathrm{HC} / 7 \alpha-\mathrm{HCO} \uparrow \\
7 \alpha, 12 \alpha-\mathrm{diHC} / 7 \alpha, 12 \alpha-\text { diHCO } \uparrow \\
27-\mathrm{HC} \text { and } 3 \beta \text {-hydroxy-5-enoic } \\
\text { ac. absents } \\
\text { (vs. controls) }\end{array}$ & {$[28]$} \\
\hline
\end{tabular}




\begin{tabular}{|c|c|c|c|c|c|c|}
\hline \multirow{6}{*}{ 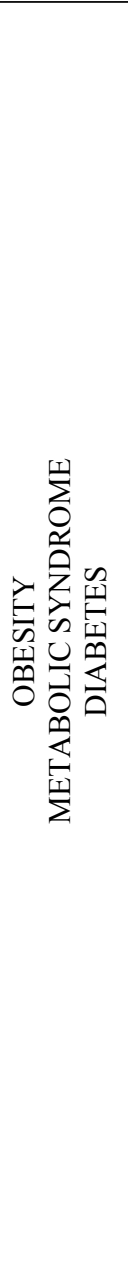 } & $\begin{array}{l}\text { isotope dilution } \\
\text { GC-MS }\end{array}$ & $\begin{array}{l}\text { obese patients with } \\
\text { type } 2 \text { diabetes }\end{array}$ & adipocytes & $\begin{array}{l}\text { (total) } \\
7-\mathrm{KC}, 7 \beta-\mathrm{HC}\end{array}$ & $\begin{array}{l}\text { 7-KC个 } 7 \beta-\mathrm{HC} \uparrow \\
\text { (vs. controls) }\end{array}$ & [31] \\
\hline & $\begin{array}{l}\text { isotope dilution } \\
\text { GC-MS }\end{array}$ & $\begin{array}{l}\text { male and female } \\
\text { obese patients and } \\
\text { metabolic syndrome } \\
\text { patients }\end{array}$ & plasma & $\begin{array}{l}\text { (total) } \\
4 \alpha \text {-HC, } 4 \beta-H C, \\
5 \alpha \text {-hydroxy-6-oxocholesterol, } 7-\mathrm{KC} \text {, } \\
7 \alpha \text {-HC, } 7 \beta \text {-HC, } 5 \alpha, 6 \alpha-E P O X, 5 \beta \\
6 \beta \text {-EPOX, TRIOL, 24S-HC, } 27-\mathrm{HC}\end{array}$ & $\begin{array}{l}\text { obese males: } 4 \alpha \text {-HC } \downarrow 4 \beta \text {-HC } \downarrow \\
\text { males with metabolic syndrome: } \\
4 \alpha-\mathrm{HC} \uparrow 4 \beta \text {-HC } \downarrow \\
\text { obese females: } 5 \alpha, 6 \alpha \text {-EPOX } \downarrow \\
4 \beta \text {-HC } \downarrow 24 \mathrm{~S}-\mathrm{HC} \downarrow \\
\text { females with metabolic } \\
\text { syndrome: } 5 \alpha, 6 \alpha \text {-EPOX } \downarrow 4 \beta \text { - } \\
\mathrm{HC} \downarrow 4 \alpha-\mathrm{HC} \uparrow 7 \alpha-\mathrm{HC} \uparrow 7 \beta-\mathrm{HC} \uparrow \\
7-\mathrm{KC} \uparrow \text { TRIOL } \uparrow 25 \text {-HC } \uparrow \\
\text { (vs. controls) }\end{array}$ & [35] \\
\hline & $\begin{array}{l}\text { semi-quantitative } \\
\text { LC-MS }\end{array}$ & $\begin{array}{l}\text { postmenopausal } \\
\text { women }\end{array}$ & serum & 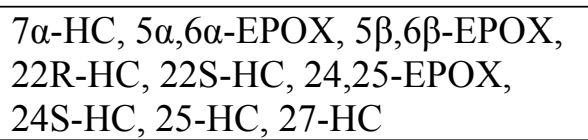 & $\begin{array}{l}\text { 22S-HC and 24,25-EPOX n.d. } \\
\text { no association with BMI }\end{array}$ & [36] \\
\hline & $\begin{array}{l}\text { semi-quantitative } \\
\text { GC-MS }\end{array}$ & adolescent girls & serum & $\begin{array}{l}\text { (total) } \\
7 \alpha-\mathrm{HC}, 7 \beta-\mathrm{HC}, 7-\mathrm{KC}, 5 \alpha, 6 \alpha \text {-EPOX, } \\
5 \beta, 6 \beta \text {-EPOX, TRIOL }\end{array}$ & $\begin{array}{l}7 \alpha-\mathrm{HC}, 7 \beta-\mathrm{HC}, 7-\mathrm{KC} \text { correlate } \\
\text { with BMI } \\
7 \alpha-\mathrm{HC}, 7 \beta-\mathrm{HC} \text { correlate with } \\
\text { fasting insulin }\end{array}$ & [37] \\
\hline & $\begin{array}{l}\text { semi-quantitative } \\
\text { GC-MS }\end{array}$ & $\begin{array}{l}\text { hypercholesterolemic } \\
\text { and diabetic patients }\end{array}$ & blood & $\begin{array}{l}4 \beta-\mathrm{HC}, 7 \alpha-\mathrm{HC}, 7 \beta-\mathrm{HC}, 7-\mathrm{KC}, \\
5 \alpha, 6 \alpha-\mathrm{EPOX}, 5 \beta, 6 \beta-\mathrm{EPOX}, \mathrm{TRIOL}, \\
25-\mathrm{HC}, 27-\mathrm{HC}\end{array}$ & $\begin{array}{l}\text { diabetic patients: } 7 \alpha-\mathrm{HC} \uparrow 7 \beta- \\
\mathrm{HC} \uparrow \\
\text { hypercholesterolemic patients: } \\
5 \alpha, 6 \alpha \text {-EPOX } \uparrow \\
\text { both patients: } 7-\mathrm{KC} \uparrow \\
\text { (vs. controls) }\end{array}$ & [38] \\
\hline & $\begin{array}{l}\text { isotope dilution } \\
\text { LC-ESI(+)-MS/MS }\end{array}$ & $\begin{array}{l}\text { type } 1 \text { and type } 2 \\
\text { diabetes patients }\end{array}$ & plasma & $\begin{array}{l}\text { (free) } \\
7-\mathrm{KC}, \mathrm{TRIOL}\end{array}$ & $\begin{array}{l}\text { both patient groups: } \\
\text { 7-KC } \uparrow \text { TRIOL } \uparrow \\
\text { (vs. controls) }\end{array}$ & [39] \\
\hline 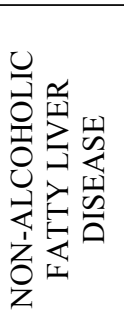 & $\begin{array}{l}\text { isotope dilution ultrafast } \\
\text { LC-MS/MS }\end{array}$ & NAFLD patients & serum & $\begin{array}{l}\text { (total) } \\
4 \beta-\mathrm{HC}, 22 \mathrm{R}-\mathrm{HC}, 24 \mathrm{~S}-\mathrm{HC}, \\
24 \mathrm{~S}, 25-\mathrm{EPOX}, 25-\mathrm{HC}, 27-\mathrm{HC} \\
\text { (free) } \\
7 \alpha-\mathrm{HCO}\end{array}$ & $\begin{array}{l}4 \beta-\mathrm{HC} \uparrow 25-\mathrm{HC} \uparrow 27-\mathrm{HC} \uparrow \\
\text { trace amounts of } 22 \mathrm{R}-\mathrm{HC} \text { and } \\
24,25-\mathrm{EPOX} \\
\text { (vs. controls) }\end{array}$ & [40] \\
\hline
\end{tabular}




\begin{tabular}{|c|c|c|c|c|c|c|}
\hline 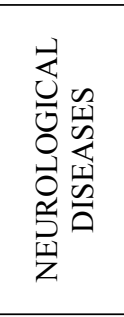 & $\begin{array}{l}\text { protein precipitation and } \\
\text { on-line SPE followed by } \\
\text { isotope dilution } \\
\text { LC-ESI(+)-MS/MS }\end{array}$ & $\begin{array}{l}\text { patients with BBB } \\
\text { dysfunctions }\end{array}$ & $\begin{array}{l}\text { CSF } \\
\text { plasma }\end{array}$ & $\begin{array}{l}\text { (free) } \\
4 \beta \text {-HC, } 5 \alpha, 6 \alpha-\text {-EPOX, } 5 \beta, 6 \beta-\mathrm{EPOX}, \\
7 \alpha / 7 \beta-\mathrm{HC}, 7-\mathrm{KC}, \mathrm{TRIOL}, 20 \alpha-\mathrm{HC}, \\
\text { 22S-HC, 22R-HC, 24S-HC, } \\
\text { 24S,25-EPOX, 25-HC, 27-HC, } \\
7 \alpha, 24-\mathrm{diHC}, 7 \alpha, 25 \text {-diHC, } \\
7 \alpha, 27-\mathrm{diHC}, 7 \alpha-\mathrm{HOCA}\end{array}$ & $\begin{array}{l}\text { CSF: } 7 \alpha-\text { HOCA } \uparrow \\
\text { (vs. patients without BBB } \\
\text { dysfunctions) }\end{array}$ & [48] \\
\hline \multirow{4}{*}{ 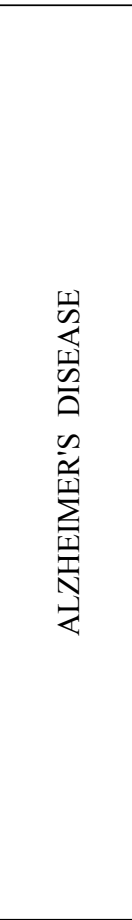 } & isotope dilution MS & $\begin{array}{l}\text { patients with } \\
\text { memory complaints }\end{array}$ & $\begin{array}{l}\text { CSF } \\
\text { plasma }\end{array}$ & $\begin{array}{l}\text { 24S-HC, 27-HC (in plasma also } \\
\text { lanosterol and lathosterol) }\end{array}$ & $\begin{array}{l}\text { CSF: 24S-HC } \uparrow 27-H C \uparrow \text { (vs. } \\
\text { controls) } \\
\text { both compounds correlate with } \\
\text { white matter hyperintensities } \\
\text { plasma: } 24 \mathrm{~S}-\mathrm{HC} \downarrow 27-\mathrm{HC} \downarrow \\
\text { (vs. controls) }\end{array}$ & {$[51]$} \\
\hline & $\begin{array}{l}\text { isotope dilution } \\
\text { GC-MS }\end{array}$ & AD patients & $\begin{array}{l}\text { brain cortex, } \\
\text { classified by the } \\
\text { Braak staging } \\
\text { system }\end{array}$ & $\begin{array}{l}\text { (total) } \\
4 \alpha-\mathrm{HC}, 4 \beta-\mathrm{HC}, 5 \alpha, 6 \alpha-\mathrm{EPOX}, \\
5 \beta, 6 \beta-\mathrm{EPOX}, 7 \alpha-\mathrm{HC} .7 \beta-\mathrm{HC}, 7-\mathrm{KC} \text {, } \\
24 \mathrm{~S}-\mathrm{HC}, 25-\mathrm{HC}, 27-\mathrm{HC}\end{array}$ & $\begin{array}{l}\text { all AD stages: } 4 \alpha-\mathrm{HC} \uparrow 4 \beta-\mathrm{HC} \uparrow \\
5 \alpha, 6 \alpha-\mathrm{EPOX} \uparrow 5 \beta, 6 \beta-\mathrm{EPOX} \uparrow \\
7 \alpha-\mathrm{HC} \uparrow 7 \beta-\mathrm{HC} \uparrow 7-\mathrm{KC} \uparrow 25- \\
\mathrm{HC} \uparrow 27-\mathrm{HC} \uparrow \\
\text { advanced AD stages: } 24 \mathrm{~S}-\mathrm{HC} \downarrow \\
\text { (vs. controls) }\end{array}$ & {$[52]$} \\
\hline & HPLC-MS & MCI patients & plasma & $\begin{array}{l}\text { (total) } \\
7 \alpha-\mathrm{HC}, 7 \beta-\mathrm{HC}, 24 \mathrm{~S}-\mathrm{HC}, 27-\mathrm{HC}\end{array}$ & $\begin{array}{l}27-\mathrm{HC} \uparrow \\
\text { (vs. controls) }\end{array}$ & [53] \\
\hline & $\begin{array}{l}\text { isotope dilution } \\
\text { GC-EI-MS } \\
\text { followed by multivariate } \\
\text { analyses of data }\end{array}$ & $\begin{array}{l}\text { MCI and AD female } \\
\text { patients }\end{array}$ & hair & $7 \alpha-\mathrm{HC}, 7 \beta-\mathrm{HC}, 24 \mathrm{~S}-\mathrm{HC}, 27-\mathrm{HC}$ & $\begin{array}{l}\text { both patient groups: } 7 \alpha-\mathrm{HC} \uparrow \\
7 \beta-\mathrm{HC} \uparrow \\
\text { significant } 7 \beta-\mathrm{HC} / \text { cholesterol } \\
\text { increase } \\
\text { (vs. controls) } \\
24 \mathrm{~S}-\mathrm{HC} \text { in trace, } 27-\mathrm{HC} \text { n.d. }\end{array}$ & {$[54]$} \\
\hline 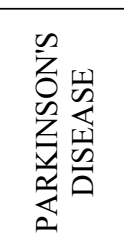 & $\begin{array}{l}\text { isotope-dilution } \\
\text { GC-EI-MS }\end{array}$ & PD patients & $\begin{array}{l}\text { brain (anterior } \\
\text { cingulate cortex, } \\
\text { amygdala, visual } \\
\text { cortex) }\end{array}$ & $\begin{array}{l}\text { (total) } \\
\text { (quantitative) } 7 \alpha-\mathrm{HC}, 7 \beta-\mathrm{HC}, 7-\mathrm{KC} \text {, } \\
\text { 24S-HC, 25-HC, 27-HC } \\
\text { (semi-quantitative) } 5 \alpha, 6 \alpha-\mathrm{EPOX}, \\
5 \beta, 6 \beta \text {-EPOX }\end{array}$ & $\begin{array}{l}\text { visual cortex: } 5 \beta, 6 \beta-\mathrm{EPOX} \uparrow \\
7 \alpha-\mathrm{HC} \uparrow 7 \beta-\mathrm{HC} \uparrow 7-\mathrm{KC} \uparrow \\
24 \mathrm{~S}-\mathrm{HC} \uparrow 25-\mathrm{HC} \uparrow 27-\mathrm{HC} \uparrow \\
\text { (vs. controls) }\end{array}$ & {$[58]$} \\
\hline 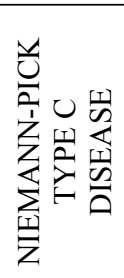 & $\begin{array}{l}\text { charge-tagging } \\
\text { derivatization followed by } \\
\text { LC-MS }\left(\mathrm{MS}^{\mathrm{n}}\right)\end{array}$ & NPC patients & plasma & $\begin{array}{l}\text { (free) } \\
\text { sterols with 7-oxo and } \\
3 \beta, 5 \alpha, 6 \beta \text { - triol functions }\end{array}$ & $\begin{array}{l}\text { compound identification and } \\
\text { semi-quantitative evaluation }\end{array}$ & [63] \\
\hline
\end{tabular}




\begin{tabular}{|c|c|c|c|c|c|c|}
\hline 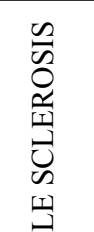 & $\begin{array}{l}\text { isotope dilution } \\
\text { LC-SIM-APCI-MS }\end{array}$ & $\begin{array}{l}\text { relapsing-remitting } \\
\text { and progressive } \\
\text { MSdis patients }\end{array}$ & plasma & $\begin{array}{l}\text { (total) } \\
7 \alpha-\mathrm{HC}, 7-\mathrm{KC}, 24 \mathrm{~S}-\mathrm{HC}, 25-\mathrm{HC} \text {, } \\
27-\mathrm{HC}\end{array}$ & $\begin{array}{l}\text { both patient groups: } 7 \alpha-\mathrm{HC} \downarrow \\
24 \mathrm{~S}-\mathrm{HC} \downarrow 27-\mathrm{HC} \downarrow \\
\text { progressive MSdis patients: } \\
\text { 7-KC } \uparrow \\
\text { (vs. controls) }\end{array}$ & [64] \\
\hline$\stackrel{\bar{G}}{\vec{\xi}}$ & $\begin{array}{l}\text { isotope dilution } \\
\text { LC-APCI }(+)-M S \\
\text { in series with PDA }\end{array}$ & MSdis patients & plasma & $\begin{array}{l}\text { (total) } \\
7 \alpha-\mathrm{HC}, 7 \beta-\mathrm{HC}, 7-\mathrm{KC}, 24 \mathrm{~S}-\mathrm{HC} \text {, } \\
27-\mathrm{HC}\end{array}$ & $\begin{array}{l}7 \alpha-\mathrm{HC} \downarrow 7 \beta-\mathrm{HC} \downarrow 7-\mathrm{KC} \downarrow \\
27-\mathrm{HC} \downarrow \\
\text { (vs. controls) }\end{array}$ & [65] \\
\hline 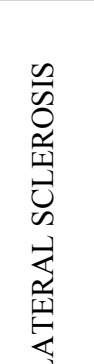 & $\begin{array}{l}\text { isotope dilution } \\
\text { GC-MS }\end{array}$ & $\begin{array}{l}\text { male and female } \\
\text { ALS patients }\end{array}$ & plasma & $\begin{array}{l}\text { (total) } \\
24 \mathrm{~S}-\mathrm{HC}, 25-\mathrm{HC}, 27-\mathrm{HC}, 7 \alpha-\mathrm{HCO}\end{array}$ & $\begin{array}{l}\text { men: } 27-\mathrm{HC} \downarrow, 24 \mathrm{~S}-\mathrm{HC} \text { and } \\
25-\mathrm{HC} \text { do not change } \\
\text { women: } 24 \mathrm{~S}-\mathrm{HC} \uparrow, 25-\mathrm{HC} \text { and } \\
27-\mathrm{HC} \text { do not change } \\
\text { (vs. controls) } \\
\text { no significant correlation } \\
\text { between oxysterols and time of } \\
\text { survival }\end{array}$ & [68] \\
\hline 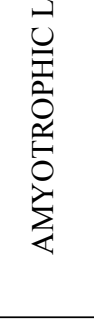 & $\begin{array}{l}\text { enzyme-assisted } \\
\text { derivatization followed by } \\
\text { LC-ESI- MS }^{\mathrm{n}}\end{array}$ & ALS patients & $\begin{array}{l}\text { CSF } \\
\text { serum }\end{array}$ & $\begin{array}{l}\text { (free) } \\
\text { over } 50 \text { cholesterol metabolites }\end{array}$ & $\begin{array}{l}\text { CSF: } 3 \beta, 7 \alpha \text {-dihydroxycholest-5- } \\
\text { en-26-oic ac. } \downarrow \\
3 \beta \text {-hydroxycholest-5-en-26-oic } \\
\text { ac. } \downarrow \\
7 \alpha \text {-hydroxy-3-oxocholest-4-en- } \\
26 \text {-oic ac. } \downarrow \\
\text { (vs. controls) }\end{array}$ & [69] \\
\hline 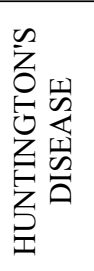 & $\begin{array}{l}\text { isotope dilution } \\
\text { GC-MS/MS }\end{array}$ & HD patients & $\begin{array}{l}\text { brain (putamen, } \\
\text { caudate, } \\
\text { cerebellum, grey } \\
\text { cortex, white } \\
\text { frontal cortex) }\end{array}$ & $\begin{array}{l}\text { (total) } \\
7 \beta-\mathrm{HC}, 7-\mathrm{KC}, 24 \mathrm{~S}-\mathrm{HC}, 27-\mathrm{HC}\end{array}$ & $\begin{array}{l}\text { putamen: } 7 \beta-\mathrm{HC} \uparrow 7-\mathrm{KC} \uparrow \\
24 \mathrm{~S}-\mathrm{HC} \downarrow 27-\mathrm{HC} \uparrow \\
\text { (vs. controls) }\end{array}$ & [70] \\
\hline 焉 & $\begin{array}{l}\text { enzyme-assisted } \\
\text { derivatization followed by } \\
\text { LC-ESI- MS }\end{array}$ & SLO patients & plasma & 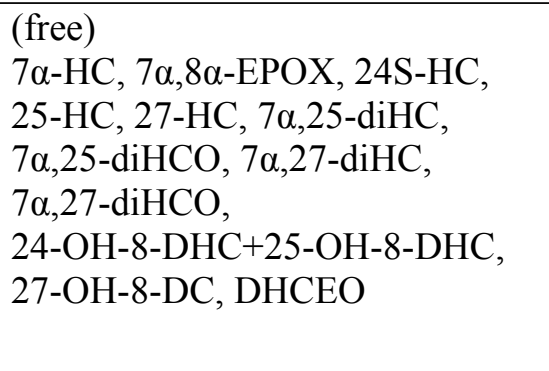 & $\begin{array}{l}7 \alpha, 8 \alpha-E P O X \uparrow 25-\mathrm{HC} \downarrow 27-\mathrm{HC} \downarrow \\
\text { (vs. controls) } \\
\text { 24-OH-8-DHC, } 25-\mathrm{OH}-8-\mathrm{DHC} \text {, } \\
27 \mathrm{OH}-8 \text {-DC, } \\
3 \beta, 5 \alpha \text {-dihydroxycholest-7-en-6- } \\
\text { one (DHCEO) non detectable in } \\
\text { controls but present in some } \\
\text { SLO patients }\end{array}$ & [72] \\
\hline
\end{tabular}




\begin{tabular}{|c|c|c|c|c|c|c|}
\hline 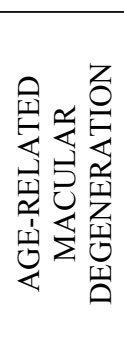 & $\begin{array}{l}\text { isotope dilution } \\
\text { HPLC-ESI(+)-MS } \\
\text { operating in MRM mode }\end{array}$ & AMD patients & $\begin{array}{l}\text { plasma } \\
\text { peripheral blood } \\
\text { monocytes }\end{array}$ & 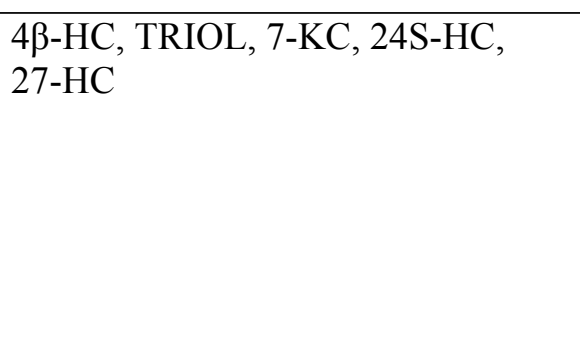 & $\begin{array}{l}\text { plasma: } 4 \beta-\mathrm{HC} \uparrow \mathrm{TRIOL} \uparrow \\
24 \mathrm{~S}-\mathrm{HC} \uparrow \\
\text { monocytes: } 7-\mathrm{KC} \uparrow \\
\text { (vs. control) } \\
\text { only } 24 \mathrm{~S}-\mathrm{HC} \text { specifically } \\
\text { associates to AMD } \\
\text { independently from age }\end{array}$ & [79] \\
\hline \multirow{4}{*}{ 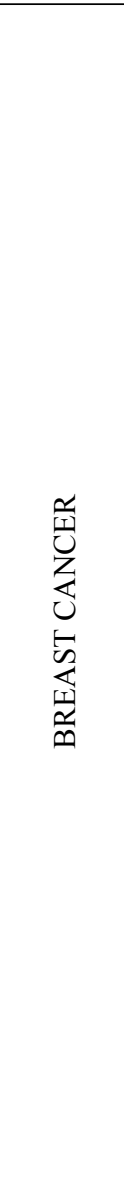 } & $\begin{array}{l}\text { isotope dilution } \\
\text { GC-MS }\end{array}$ & $\begin{array}{l}\text { BC patients in } \\
\text { treatment with } \\
\text { Tamoxifen or with } \\
\text { aromatase inhibitors }\end{array}$ & serum & $\begin{array}{l}\text { (total) } \\
4 \beta-\mathrm{HC}, 5 \alpha, 6 \alpha-\mathrm{EPOX}, 5 \beta, 6 \beta-\mathrm{EPOX} \text {, } \\
\text { OCDO, } 7 \alpha-\mathrm{HC}, 7 \beta-\mathrm{HC}, 7-\mathrm{KC}, \\
\text { TRIOL, 24S-HC, 25-HC, 27-HC }\end{array}$ & $\begin{array}{l}\text { Tamoxifen treatment: } 4 \beta-\mathrm{HC} \uparrow \\
7 \alpha-\mathrm{HC} \downarrow 24 \mathrm{~S}-\mathrm{HC} \downarrow 25-\mathrm{HC} \downarrow \\
\text { aromatase inhibitors treatment: } \\
5 \beta, 6 \beta-\mathrm{EPOX} \uparrow 7-\mathrm{KC} \uparrow 25-\mathrm{HC} \uparrow \\
27-\mathrm{HC} \uparrow \\
\text { (vs. baseline) }\end{array}$ & [83] \\
\hline & $\begin{array}{l}\text { isotope dilution } \\
\text { GC-MS }\end{array}$ & BC patients & $\begin{array}{l}\text { breast tissue } \\
\text { breast cells }\end{array}$ & $\begin{array}{l}5 \alpha, 6 \alpha-\mathrm{EPOX}, 5 \beta, 6 \beta-\mathrm{EPOX}, \mathrm{TRIOL}, \\
\text { OCDO }\end{array}$ & $\begin{array}{l}\text { breast tissue: } 5 \alpha, 6 \alpha \text {-EPOX } \uparrow \\
5 \beta, 6 \beta \text {-EPOX } \uparrow \text { TRIOL } \uparrow \text { OCDO } \uparrow \\
\text { (vs. paired normal adjacent } \\
\text { tissue) }\end{array}$ & {$[85]$} \\
\hline & $\begin{array}{l}\text { isotope dilution } \\
\text { UPLC-APCI(+)-MS/MS }\end{array}$ & $\begin{array}{l}\text { BC patients before } \\
\text { and after tumor } \\
\text { removal }\end{array}$ & plasma & 7 $\alpha-\mathrm{HC}, 7-\mathrm{KC}, 25-\mathrm{HC}, 27-\mathrm{HC}$ & $\begin{array}{l}\text { after tumor removal: 7-KC个 } \\
\text { (vs. paired sampling before } \\
\text { tumor removal) }\end{array}$ & [86] \\
\hline & $\begin{array}{l}\text { Girard T derivatization } \\
\text { followed by isotope } \\
\text { dilution fast LC-MS/MS } \\
\text { coupled with on-line } \\
\text { sample clean-up system }\end{array}$ & $\begin{array}{l}\text { estrogen receptor } \\
\text { positive and estrogen } \\
\text { receptor negative BC } \\
\text { patients }\end{array}$ & $\begin{array}{l}\text { BC tumor } \\
\text { (consecutive } \\
\text { slices) }\end{array}$ & $\begin{array}{l}\text { (free and total) } \\
\text { 22R-HC, 24S-HC, 25-HC, 27-HC }\end{array}$ & $\begin{array}{l}\text { large intra-tumor variations of all } \\
\text { oxysterols } \\
\text { no significant differences in } \\
\text { oxysterol amounts between } \\
\text { estrogen receptor positive and } \\
\text { estrogen receptor negative BC } \\
\text { significant correlation between } \\
\text { free and esterified } 27-\mathrm{HC} \text { and } \\
25-\mathrm{HC} \text { in estrogen receptor } \\
\text { positive BC }\end{array}$ & [89] \\
\hline
\end{tabular}




\begin{tabular}{|c|c|c|c|c|c|c|}
\hline 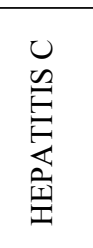 & $\begin{array}{l}\text { piconyl ester } \\
\text { derivatization followed by } \\
\text { isotope dilution } \\
\text { HPLC-ESI-MS/MS }\end{array}$ & $\begin{array}{l}\text { chronic hepatitis } \mathrm{C} \\
\text { patients }\end{array}$ & serum & $\begin{array}{l}\text { (total) } \\
4 \beta-\mathrm{HC}, 7 \alpha-\mathrm{HC}, 22 \mathrm{R}-\mathrm{HC}, 24 \mathrm{~S}-\mathrm{HC}, \\
25-\mathrm{HC}, 24 \mathrm{~S}, 25-\mathrm{EPOX}, 27-\mathrm{HC} \\
\text { (free) } \\
7 \alpha-\mathrm{HCO}\end{array}$ & $\begin{array}{l}4 \beta-\mathrm{HC} \uparrow 7 \alpha-\mathrm{HC} \uparrow 25-\mathrm{HC} \uparrow \\
\text { (vs. control) }\end{array}$ & [90] \\
\hline 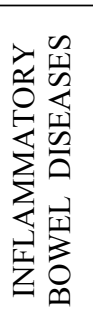 & $\begin{array}{l}\text { semi-quantitative } \\
\text { HPLC-APCI(+)-MS }\end{array}$ & $\begin{array}{l}\text { Crohn's disease } \\
\text { patients and } \\
\text { ulcerative colitis }\end{array}$ & colon & $\begin{array}{l}\text { (free) } \\
4 \beta-\mathrm{HC}, 5 \alpha, 6 \alpha-\mathrm{EPOX}, 5 \beta, 6 \beta-\mathrm{EPOX}, \\
5 \beta, 6 \beta-\mathrm{diHC}, 7 \alpha-\mathrm{HCO}, 7-\mathrm{HC}, 7-\mathrm{KC} \text {, } \\
25-\mathrm{HC}, 27-\mathrm{HC}\end{array}$ & $\begin{array}{l}7 \alpha-\mathrm{HCO} \uparrow 25-\mathrm{HC} \uparrow 27-\mathrm{HC} \downarrow \\
\text { (vs. control) }\end{array}$ & [95] \\
\hline
\end{tabular}




\section{Table 2.}

Oxysterol evaluation in pathological conditions by lipidomics analyses of animal specimens. (total: an alkaline hydrolysis step was performed to give free and esterified oxysterols)

\begin{tabular}{|c|c|c|c|c|c|c|}
\hline PATHOLOGY & $\begin{array}{l}\text { ANALYTICAL } \\
\text { ASPECTS }\end{array}$ & SUBJECTS & SPECIMEN & ANALYTES & MAIN OBSERVATIONS & REF. \\
\hline \multirow[b]{3}{*}{ 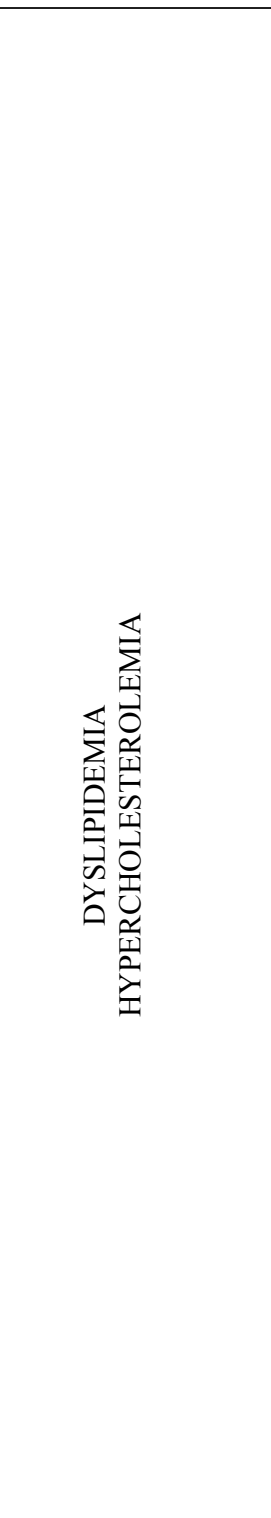 } & $\begin{array}{l}\text { isotope dilution } \\
\text { GC-MS/MS }\end{array}$ & $\begin{array}{l}\text { trained dyslipidemic } \\
\text { mice }\end{array}$ & $\begin{array}{l}\text { plasma } \\
\text { aortic arch }\end{array}$ & $\begin{array}{l}\text { (total) } \\
7 \alpha-\mathrm{HC}, 7 \beta-\mathrm{HC}, 7-\mathrm{KC}, \\
25-\mathrm{HC}, 27-\mathrm{HC}\end{array}$ & $\begin{array}{l}\text { plasma: no change for all oxysterols } \\
\text { aortic arch: } 7 \beta-\mathrm{HC} \uparrow \\
25-\mathrm{HC} \text { and } 27-\mathrm{HC} \text { n.d. } \\
\text { (vs. sedentary mice) }\end{array}$ & [22] \\
\hline & GC-MS & $\begin{array}{l}\text { hamsters fed high } \\
\text { cholesterol diet with or } \\
\text { without antioxidant } \\
\text { supplementation }\end{array}$ & liver & $\begin{array}{l}\text { (total) } \\
\text { 7-KC, 24S-HC, } \\
25-\mathrm{HC}, 27-\mathrm{HC}\end{array}$ & $\begin{array}{l}25-\mathrm{HC} \uparrow 27-\mathrm{HC} \uparrow \\
\text { (vs. hamsters fed high cholesterol diet free of } \\
\text { antioxidants) }\end{array}$ & [23] \\
\hline & $\begin{array}{l}\text { isotope dilution } \\
\text { LC-SIM-APCI-MS }\end{array}$ & $\begin{array}{l}\text { female mice and paired } \\
\text { newly-weaned } \\
\text { offspring fed high } \\
\text { cholesterol diet with or } \\
\text { without phytosterol } \\
\text { supplementation }\end{array}$ & $\begin{array}{l}\text { serum } \\
\text { liver }\end{array}$ & $\begin{array}{l}\text { (total) } \\
7 \alpha-\mathrm{HC}, 7 \beta-\mathrm{HC}, 7-\mathrm{KC}, \\
24 \mathrm{~S}-\mathrm{HC}, 25-\mathrm{HC}, \\
27-\mathrm{HC}\end{array}$ & 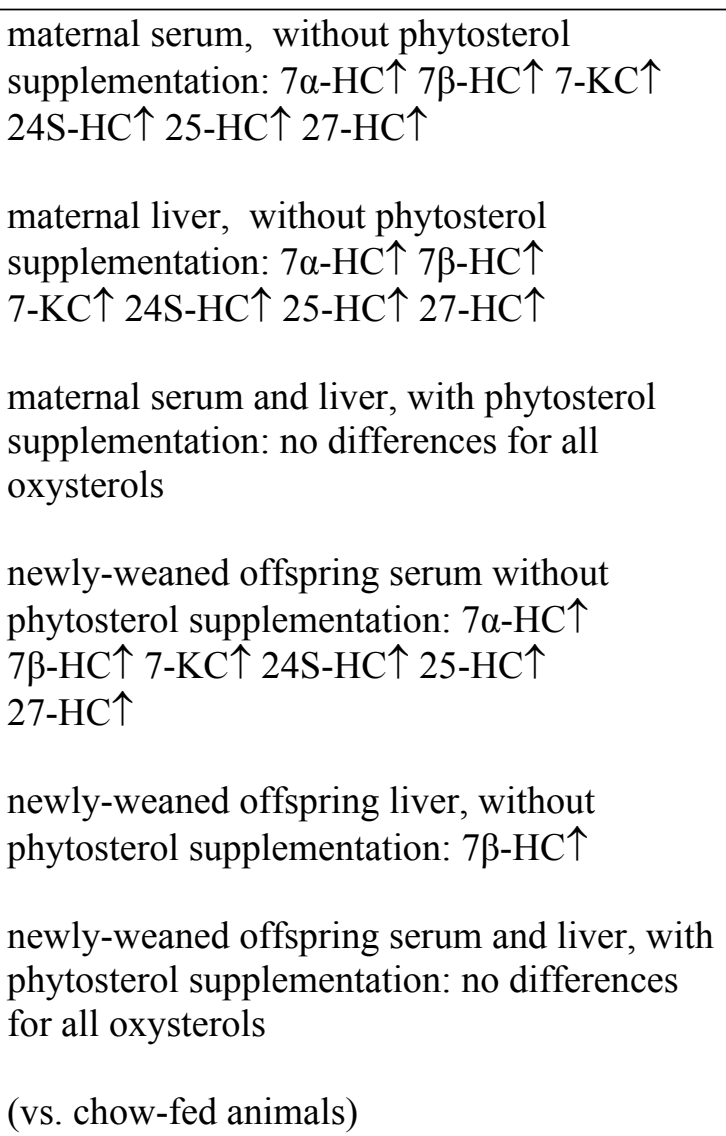 & [24] \\
\hline
\end{tabular}




\begin{tabular}{|c|c|c|c|c|c|c|}
\hline 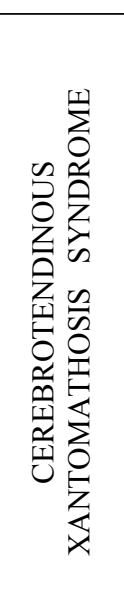 & $\begin{array}{l}\text { enzyme-assisted } \\
\text { charge-tagging } \\
\text { derivatization } \\
\text { followed by } \\
\text { LC-ESI-MS }\end{array}$ & $\begin{array}{l}\text { Cyp27A1 knock-down } \\
\text { mice }\end{array}$ & $\begin{array}{l}\text { plasma } \\
\text { brain }\end{array}$ & $\begin{array}{l}\text { (free) } \\
\text { over } 50 \text { cholesterol } \\
\text { metabolites and } \\
\text { precursors }\end{array}$ & $\begin{array}{l}\text { formation of }(25 \mathrm{R}) 26,7 \alpha \text { - and }(25 \mathrm{~S}) 26,7 \alpha- \\
\text { dihydroxy epimers of oxysterols and } \\
\text { cholestenoic acids } \\
\text { wild type mice plasma: } \\
7 \alpha \text {-hydroxy-3-oxocholest-4-en-(25R)26-oic } \\
\text { ac. > 7 -hydroxy-3-oxocholest-4-en-(25S)26- } \\
\text { oic ac. } \\
\text { knock-down mice plasma: } \\
7 \alpha \text {-hydroxy-3-oxocholest-4-en-(25S)26-oic } \\
\text { ac. }>7 \alpha \text {-hydroxy-3-oxocholest-4-en-(25R)26- } \\
\text { oic ac. }\end{array}$ & [29] \\
\hline \multirow{2}{*}{ 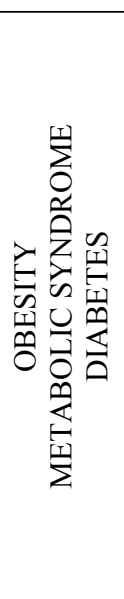 } & $\begin{array}{l}\text { isotope dilution } \\
\text { GC-MS }\end{array}$ & $\begin{array}{l}\text { male mice fed a high } \\
\text { cholesterol diet }\end{array}$ & $\begin{array}{l}\text { plasma } \\
\text { liver } \\
\text { adipose tissue }\end{array}$ & $\begin{array}{l}\text { (total) } \\
4 \beta-\mathrm{HC}, 5 \alpha, 6 \alpha-\mathrm{EPOX}, \\
5 \beta, 6 \beta-\mathrm{EPOX}, 7 \alpha-\mathrm{HC}, \\
7 \beta-\mathrm{HC}, 7-\mathrm{KC}, 25-\mathrm{HC}, \\
27-\mathrm{HC}\end{array}$ & $\begin{array}{l}\text { plasma: } 4 \beta-\mathrm{HC} \uparrow 5 \alpha, 6 \alpha-\mathrm{EPOX} \uparrow \\
5 \beta, 6 \beta-\mathrm{EPOX} \uparrow 7 \alpha-\mathrm{HC} \uparrow 7 \beta-\mathrm{HC} \uparrow \\
27-\mathrm{HC} \uparrow \\
\text { liver: } 4 \beta-\mathrm{HC} \uparrow \\
\text { adipose tissue: } 4 \beta-\mathrm{HC} \uparrow 27-\mathrm{HC} \uparrow \\
\text { (vs. chow-fed animals) }\end{array}$ & [32] \\
\hline & $\begin{array}{l}\text { isotope dilution } \\
\text { HPLC-APCI }(+)-M S\end{array}$ & $\begin{array}{l}\text { male mice fed a high } \\
\text { cholesterol diet }\end{array}$ & $\begin{array}{l}\text { liver } \\
\text { adipose tissue }\end{array}$ & $\begin{array}{l}\text { (free) } \\
4 \beta \text {-HC, } 5 \alpha, 6 \alpha-\mathrm{EPOX}, \\
5 \beta, 6 \beta-\mathrm{EPOX}, \\
5 \alpha, 6 \beta-\mathrm{diHC}, 7 \alpha-\mathrm{HC}, \\
7 \alpha-\mathrm{HCO}, 7-\mathrm{KC}, \\
25-\mathrm{HC}, 7 \alpha, 25-\mathrm{diHC}, \\
7 \alpha, 27-\mathrm{diHC}, 27-\mathrm{HC}\end{array}$ & $\begin{array}{l}\text { liver: } 4 \beta \text {-HC } \downarrow 7 \alpha, 25 \text {-diHC } \downarrow \\
7 \alpha-\mathrm{HCO} \uparrow 27-\mathrm{HC} \uparrow \\
\text { adipose tissue: } 7 \alpha, 27 \text {-diHC n.d. } \\
\text { no change for the other oxysterols } \\
\text { (vs. lean mice) }\end{array}$ & [33] \\
\hline 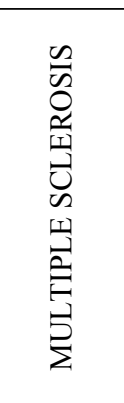 & $\begin{array}{l}\text { semi-quantitative } \\
\text { LC-APCI-MS }\end{array}$ & $\begin{array}{l}\text { MSdis model } \\
\text { (experimental } \\
\text { autoimmune } \\
\text { encephalomyelitis) } \\
\text { mice }\end{array}$ & brain stem & $\begin{array}{l}\text { (free) } \\
4 \beta-\mathrm{HC}, 5 \alpha, 6 \alpha-\mathrm{EPOX}, \\
5 \beta, 6 \beta-\mathrm{EPOX}, \\
5 \alpha, 6 \beta \text {-diHC, } 7-\mathrm{HC}, \\
7-\mathrm{KC}, 7 \alpha-\mathrm{HCO}, \\
24 \mathrm{~S}-\mathrm{HC}, \\
\text { 24S,25-EPOX, } \\
7 \alpha, 25-\mathrm{diHC}, 27-\mathrm{HC}, \\
7 \alpha, 27-\mathrm{diHC}\end{array}$ & $\begin{array}{l}5 \alpha, 6 \beta-\text { diHC } \downarrow \text { 7-KC } \downarrow 24 \mathrm{~S}, 25 \text {-EPOX } \downarrow \\
7 \alpha, 25 \text {-diHC } \uparrow \\
\text { (vs. control) }\end{array}$ & [49] \\
\hline
\end{tabular}




\begin{tabular}{|c|c|c|c|c|c|c|}
\hline \multirow{3}{*}{ 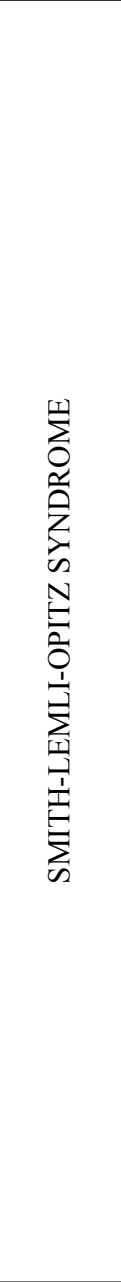 } & $\begin{array}{l}\text { semi-quantitative } \\
\text { HPLC-APCI-MS/MS }\end{array}$ & $\begin{array}{l}\text { genetic SLO mouse } \\
\text { model }\end{array}$ & $\begin{array}{l}\text { brain } \\
\text { liver }\end{array}$ & 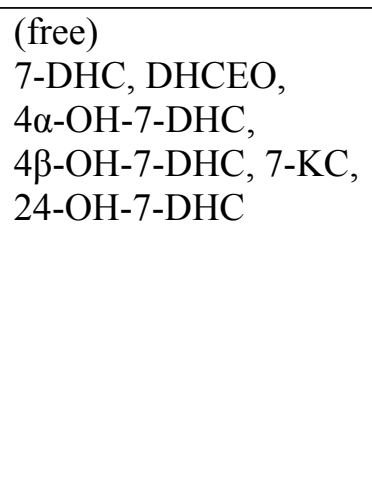 & $\begin{array}{l}\text { SLO mice: presence of all oxysterols in both } \\
\text { tissues } \\
\text { brain 7-DHC and DHCEO }>\text { liver 7-DHC and } \\
\text { DHCEO } \\
\text { brain } 4 \alpha \text { - and } 4 \beta \text {-hydroxy-7-DHC }<\text { liver } 4 \alpha- \\
\text { and } 4 \beta \text {-hydroxy-7-DHC } \\
\text { wild type-mice: 7-DHC, DHCEO, } \\
4 \alpha-O H-7-D H C, 4 \beta-O H-7-D H C, 4-O H-7-D H C \\
\text { n.d. in both tissues }\end{array}$ & [73] \\
\hline & $\begin{array}{l}\text { enzyme-assisted } \\
\text { charge-tagging } \\
\text { derivatization } \\
\text { followed by semi- } \\
\text { quantitative } \\
\text { LC-ESI-MS }\end{array}$ & SLO mouse model & brain & $\begin{array}{l}\text { (free) } \\
6 \beta-\mathrm{HC}, 7 \beta-\mathrm{HC}, \\
7-\mathrm{DHC} \text { and its } \\
\text { derivatives, } 8 \text {-DHC, } \\
24 \mathrm{~S}-\mathrm{HC}, \\
24 \mathrm{~S}, 25-\mathrm{EPOX}\end{array}$ & $\begin{array}{l}6 \beta-\mathrm{HC} \uparrow 7 \beta-\mathrm{HC} \uparrow 7-\mathrm{DHC} \uparrow \\
7-\mathrm{DHC} \text { derivatives } \uparrow 8-\mathrm{DHC} \uparrow \\
\text { 24S-HC } \downarrow 24 \mathrm{~S}, 25-\mathrm{EPOX} \downarrow \\
\text { (vs. wild type mice) }\end{array}$ & [74] \\
\hline & $\begin{array}{l}\text { semi-quantitative } \\
\text { HPLC-APCI-MS/MS }\end{array}$ & SLO rat model & $\begin{array}{l}\text { brain } \\
\text { liver } \\
\text { serum }\end{array}$ & $\begin{array}{l}\text { (free in brain and } \\
\text { liver, total in serum) } \\
7-\mathrm{DHC}, \\
4 \alpha-\mathrm{OH}-7-\mathrm{DHC}, \\
4 \beta-\mathrm{OH}-7-\mathrm{DHC}, \\
\text { DHCEO, 7-KC, } \\
24-\mathrm{OH}-7-\mathrm{DHC}\end{array}$ & $\begin{array}{l}\text { 7-DHC, } 4 \alpha-\mathrm{OH}-7-\mathrm{DHC}, 4 \beta-\mathrm{OH}-7-\mathrm{DHC}, \\
\text { DHCEO, 24-OH-7-DHC n.d. in all tissues of } \\
\text { control animals } \\
\text { brain and liver: 7-KC } \uparrow \\
\text { (vs. control animals) } \\
\text { the method does not allow quantification of } \\
\text { serum } 4 \alpha-\mathrm{OH}-7-\mathrm{DHC}, 4 \beta-\mathrm{OH}-7-\mathrm{DHC} \text {, } \\
\text { 7-KC }\end{array}$ & [75] \\
\hline 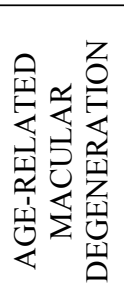 & $\begin{array}{l}\text { Isotope dilution } \\
\text { HPLC-ESI-MS }\end{array}$ & cholesterol-fed rabbits & retina & $\begin{array}{l}\text { (total) } \\
4 \beta-\mathrm{HC}, 7 \alpha-\mathrm{HC}, \\
22-\mathrm{HC}, 24 \mathrm{~S}-\mathrm{HC}, \\
25-\mathrm{HC}, 27-\mathrm{HC}\end{array}$ & $\begin{array}{l}\text { all oxysterols } \uparrow \\
\text { (vs. chow-fed animals) }\end{array}$ & [78] \\
\hline
\end{tabular}




\begin{tabular}{|c|c|c|c|c|c|c|}
\hline 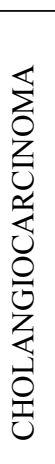 & $\begin{array}{l}\text { semi-quantitative } \\
\text { GC-MS }\end{array}$ & $\begin{array}{l}\text { liver fluke-infected } \\
\text { hamsters }\end{array}$ & liver & $\begin{array}{l}\text { (total) } \\
\text { 3-K4, 3-K7, 3-KD, } \\
\text { 7-KD, TRIOL }\end{array}$ & $\begin{array}{l}3-\mathrm{K} 4 \uparrow \mathrm{TRIOL} \uparrow \\
\text { (vs. control animals) }\end{array}$ & [91] \\
\hline 恣 & $\begin{array}{l}\text { semi-quantitative } \\
\text { HPLC-APCI(+)-MS }\end{array}$ & $\begin{array}{l}\text { acute and chronic } \\
\text { colitis mouse model }\end{array}$ & $\begin{array}{l}\text { colon } \\
\text { plasma }\end{array}$ & $\begin{array}{l}\text { (free) } \\
4 \beta-\mathrm{HC}, 5 \alpha, 6 \alpha-\mathrm{EPOX}, \\
5 \beta, 6 \beta \text {-EPOX, } \\
5 \beta, 6 \beta \text {-diHC, } 7-\mathrm{HC}, \\
7 \alpha-\mathrm{HCO}, 7-\mathrm{KC}, \\
25-\mathrm{HC}, 7 \alpha, 25 \mathrm{diHC}, \\
27-\mathrm{HC}\end{array}$ & $\begin{array}{l}\text { colon: } 4 \beta-\mathrm{HC} \uparrow \text { in all colitis models } \\
\text { (vs. control animals) }\end{array}$ & [95] \\
\hline
\end{tabular}

